\title{
Geo-Environmental Site Investigation for Municipal Solid Waste Disposal Sites
}

\author{
Giulliana Mondelli, Heraldo Luiz Giacheti and Vagner Roberto Elis \\ Institute for Technological Research of São Paulo State, \\ São Paulo State University, University of São Paulo, São Paulo, \\ Brazil
}

\section{Introduction}

Deactivated dump sites and inadequate sanitary landfills can be a serious potential source of contamination. Due to the large number of these sites, contaminants can be generated and migrate into the ground. For this reason, site investigation programs which consider different types of soils and contaminants are needed. In many countries, sanitary landfills have been recently built according to the engineering standards with satisfactory procedures and following the requirements imposed by the local environmental agencies, including monitoring and proper operations. There is a great concern with the operation of sanitary landfills and with the future of deactivated dump sites located in small and medium-size cities, since many of them were inappropriately constructed and operated. Consequently, the main surficial streams and groundwater aquifers, subsoil and air become vulnerable to contamination and pollution. A continuous site investigation program, including in-situ and laboratory tests are necessary to identify the typical soil profile, hydrogeological characteristics and background chemical values. The site surroundings and the subsoil contamination plume can be characterized based on geotechnical, geochemical and mineralogical techniques.

The demand for the geo-environmental site investigation of contaminated and noncontaminated sites intended for future sanitary landfill planning has substantially increased in the last few years due to the lack of space in metropolitan areas.

Environmental agencies from several countries have proposed different site investigation methodologies in order to diagnose and confirm different contamination levels in sites with diverse physical characteristics in order to guide the remediation plan whenever it is necessary. The experience already achieved on site investigations has shown that the best methodology is site specific, and depends on subsoil and chemical contaminants; geotechnical, geological and hydrogeological aspects; evolution of the contamination plume and the possible risks it poses. Several field and laboratory investigation techniques (direct and indirect) have been proposed and used. Sometimes one technique is more suitable than another depending on the physical and natural characteristics of the site. Countries with recent concerns over the environment tend to adapt the experience gained from the more 
developed countries with the reality of their own environmental laws, economy, industrialization, size, etc.

Having outlined this scenario, this chapter aims to present and discuss the different tests and steps of a geo-environmental site investigation program proposed for municipal solid waste disposal sites.

\section{Geo-environmental site investigation steps}

The various steps that can be included during a geo-environmental site investigation are discussed in this item and can be systematized in the chart shown in Figure 1, which was prepared considering experience gained on several geo-environmental site characterization campaigns at municipal solid waste disposal sites in Brazil. The major focus of these studies was to assess contamination of medium size municipal solid waste disposal sites, installed over typical Brazilian tropical soils (residual soils and sandstones).

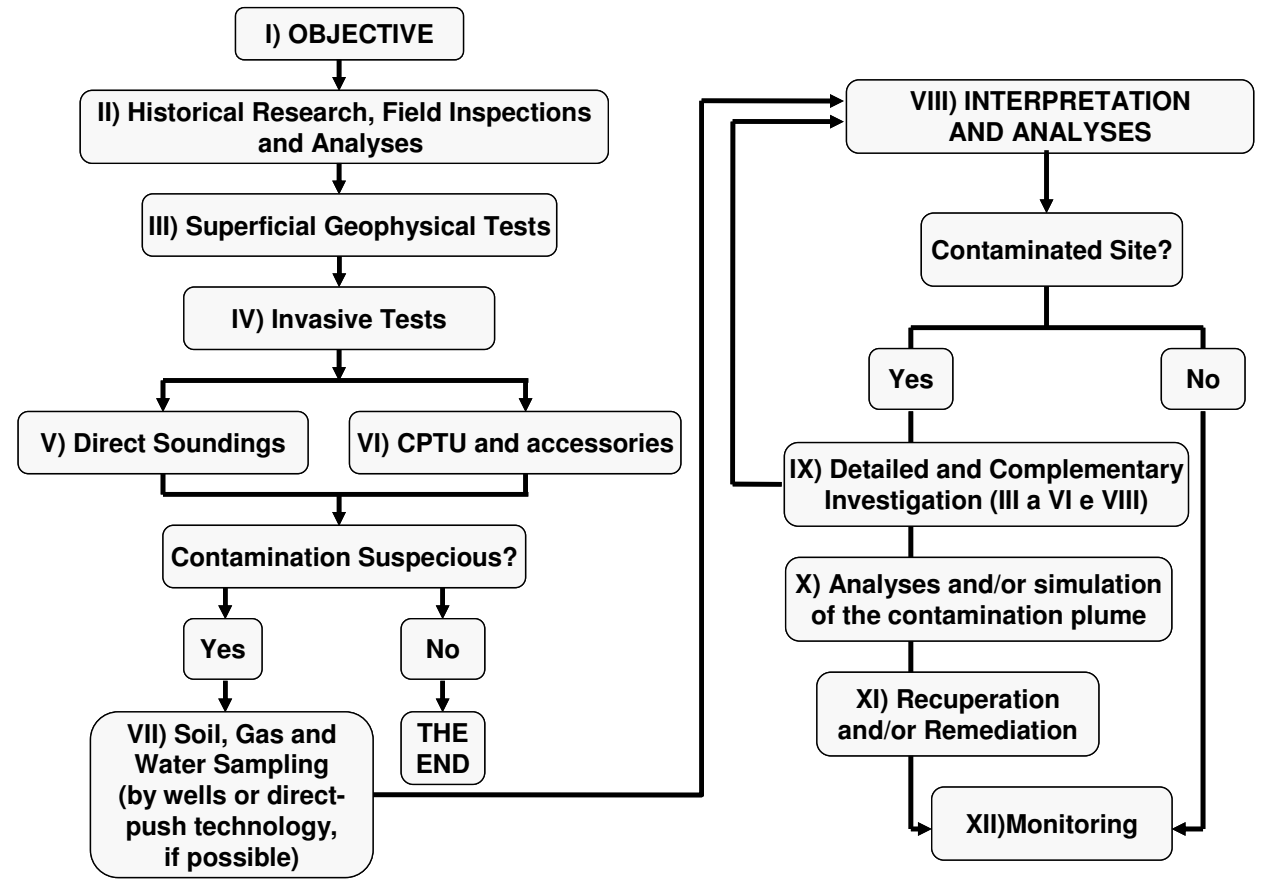

Fig. 1. Proposed geo-environmental site investigation steps for municipal solid waste disposal sites (Mondelli, 2008).

It is important to emphasize that the very first step in any site investigation program is to define the problem. For example, if the objective of the site investigation is just to characterize the local subsoil before the installation of a sanitary landfill, it will probably be necessary to carried out the site investigation until the fifth or sixth step presented in the Figure 1. Depending of the enterprise size or of the natural environmental and anthropological site conditions, the contamination will be assessed in a later step. Therefore, 
before starting any site investigation test it is fundamental to clearly define the objective of the site investigation program and determine the possible sources and/or targets of contamination. If the sources and/or targets do not exist, there is no sense in continuing the site investigation after the seventh step (Figure 1).

\section{Preliminary investigation}

Environmental agencies usually recommend gathering historical information and carrying out a site inspection during the preliminary investigation. Compilation of physical and historical data and all the existing information about the site need to be collected before starting any site investigation. This phase (second step in Figure 1) has proved to be very important for the future steps, based on the interpretation of the previous and current topography, hydrology, aerial photographs and historical documents. A good job in this phase can avoid unnecessary tests in the next steps of the site investigation, reducing costs without compromising the quality of the final results.

Before installing a new sanitary landfill, closing an old dump or in a regular landfill, or just to investigate the extension of a contamination plume caused by leachate from an irregular municipal solid waste disposal site, it is necessary to contact the responsible company and environmental agencies involved, visit the site and request the following data:

1. Location: geographical coordinates, original and current topography, distance from the urban zone, access, surroundings, rivers and airport proximity. Depending on the local regulations, some of these aspects may constrain the construction or extension of new sanitary landfills and may also help the site investigation plan and the final design.

2. Municipal waste management: information such as amounts of municipal, hospital, demolition/construction and sweeping/pruning waste generated per person and the locations and manner in which they are disposed of, also needs to be checked. Furthermore, some questions need to be addressed, like: "How long the current landfill will continue to operate? Has it obtained operating and/or commissioning licenses? Is there a plan for hazardous waste management? What percentage of the waste is recycled by the municipality? Are there any environmental education programs for the local community?"

3. Aerial photography: a very complete study of the site to be investigated, its uses and occupational activities and physical surrounds can be done by using aerial photography taken over a period of time up to present day photos.

4. Old reports: reports of past site investigations and geological surveys need to be available for consultation and search of the physical media data to be also used or supplemented during the new site investigation phase.

5. Weather Aspects: climate data, such as mean annual temperatures, rainfall, radiation, etc for the city or that region where the site investigation will be conducted, should be collected for analysis and calculation of the water balance. The water balance can be carried out using the Thornthwaite and Mather (1955) methodology.

After the analyses and interpretation of all integrated existing data from the site to be investigated, a Preliminary Investigation Report can be submitted. Therefore, the site investigation plan will be planned and conducted based on all information collected on site, 
facilitating the achievement of the final objective of the site investigation, in order to reduce time and costs. Sometimes, this next phase is called Confirmatory Investigation, when suspicion of contamination occurs. More recently, this phase can integrate the use of different field and laboratory tests. The most well known and widely used tests are surficial geophysics (non-invasive and indirect techniques), followed by piezocone tests (CPTU) (invasive and indirect/direct techniques) with special sensors and samplers for environmental purposes, and groundwater level monitoring wells. Accordingly with Figure 1 , some of these techniques, which are more frequently used for geo-environmental site investigation purposes, will be briefly discussed.

\section{Geophysical survey}

Geophysical methods, particularly electrical techniques, can be used to study those different environmental characteristics which are important during the site characterization for waste disposal and the monitoring of migratory contamination plumes. The major advantage of these methods is that the measurements of soil and contaminant properties are indirect, but it can also be a disadvantage too. It allows a quick investigation of a large area avoiding direct contact with contaminants.

Direct techniques based on previous tests, such as simple reconnaissance boring with Standard Penetration Test (SPT) and monitoring through groundwater wells and piezometers, can be used and are considered a traditional practice in developing countries. In this context, much effort has been concentrated on measuring electrical resistivity, a property that is highly dependent on lithology and contamination, which are essential factors to be detected during a geo-environmental site investigation. The major interest in measuring electrical resistivity in a geo-environmental site investigation of contaminated sites is due to the fact that it is an indirect measurement that can be achieved by means of subsurface and/or surface tests, which is also sensitive to temporal variations of the physical environment. This also allows it to be used as a monitoring technique and not only as a method for the investigation and initial reconnaissance of the subsoil.

The following geological, geotechnical, hydrogeological and environmental characteristics can be assessed using geophysical methods: (a) rock depth; (b) discontinuities; (c) changes of soil texture; (d) groundwater level; (e) groundwater flow; (f) presence and threedimensional distribution of waste; (g) contaminated soil; (h) contaminated groundwater and plume shape. The first five characteristics are essential for the assessment of any waste disposal sites. All these submitted characteristics are recommended in the geoenvironmental monitoring of a waste disposal facility. The geophysical methods which present good results for these applications are the Resistivity and the Low Frequency Electromagnetics (Ground Conductivity Meters).

\subsection{Resistivity}

The Resistivity Method applies an artificial electrical current $I$, introducing two electrodes into the ground (A and $\mathrm{B}$ ), with the objective of measuring the differential potential $\Delta V$ generated by two other electrodes ( $\mathrm{M}$ and $\mathrm{N}$ ) in the electrical current flow extremities (Figure 2). This arrangement allows the calculation of apparent resistivity $\rho_{a}$ in subsurface, using the following equation: 


$$
\rho_{a}=K \cdot \frac{\Delta V}{I}(\mathrm{ohm} \cdot \mathrm{m})
$$

where $K$ is a geometrical factor that depends on the electrodes position in the ground and can be calculated for any electrode arrangement using the following general expression:

$$
K=\frac{2 \pi}{(1 / A M)-(1 / A N)-(1 / B M)+(1 / B N)}(\mathrm{m})
$$

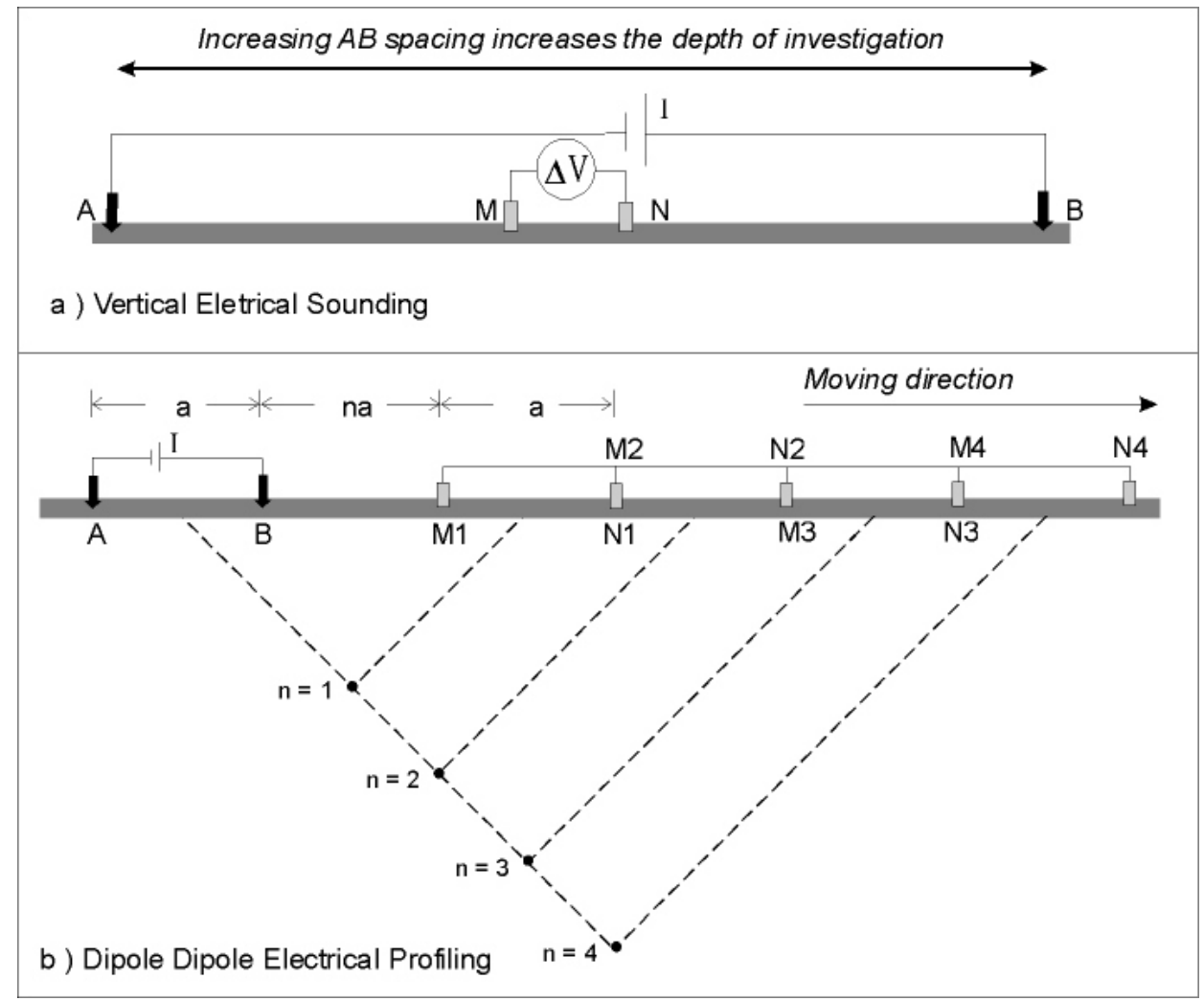

Fig. 2. Configuration of 1D and 2D resistivity surveys: (a) Vertical Electrical Sounding and (b) Dipole Dipole Electrical Profiling.

The soil and rock resistivity values are affected mainly by four factors: mineralogy composition, porosity, moisture, amount and nature of dissolved salts. The most important factors are the porous water content and the salinity content in the porous media. The increase of these two factors tends to decrease the resistivity values. These characteristics allow a good applicability of this geophysical method of application in environmental and hydrogeological studies, where inorganic contaminants occur. In the specific case of municipal solid waste disposal sites, the formation of leachate with elevated concentration of ions, characterizing the polluted areas with very low resistivity values. 
The equipment used for the resistivity method consists basically of a controlled electrical current source emission and differential potential measurements. The source potential can range from some kilowatts up to hundreds of watts. This equipment can work using direct or alternating current supply with low frequency, preferably lower than $60 \mathrm{~Hz}$ (Telford et al., 1990).

The Resistivity Method encompasses various techniques for the application of field tests, which basically consist of vertical electrical sounding (1D resistivity survey) and electrical profiling (2D resistivity imaging) and includes a wide variety of possible electrode configurations (Schlumberger, Wenner, Dipole Dipole, Pole Dipole, Lee and other), rendering the method highly versatile. Currently, 3D tests are possible with the use of multielectrode equipment or a series of 2D profiles grouped and equidistant (Loke \& Barker, 1996; Dahlin et al., 2002). Figure 2 presents electrical soundings and dipole dipole electrical profiling field arrangements. As the subsoil is not homogeneous, for any measurement point an apparent resistivity value is obtained. Appropriate software is used for data acquisition and interpretation, for obtaining the electrical stratigraphy of the subsoil (1D survey) or the resistivity cross-section (2D survey). There are several possibilities for carrying out these tests allowing the use of different techniques and arrangements, depending on the site investigation objectives. Usually the most important objective of a geo-environmental characterization is to delineate contamination plumes.

The vertical electrical soundings can give important information on site characterization of waste disposal sites. The distribution of different geomaterials on the subsurface profile (several soil layers, waste and rock substrate top) and the depth of the saturated zone can be estimated using vertical electrical soundings. Figure 3 presents the results and the interpretation of a vertical electrical sounding carried out to expand the knowledge of the stratigraphy profile and for defining the position of the saturated zone. The combined results obtained from several vertical electrical soundings allow the construction of a contour map of the groundwater level showing the direction of the groundwater flow.

Waste disposal sites can be mapped using several vertical electrical soundings (VES) points or using electrical profiling (continuous way). The VES are more appropriate to vertical subsoil profile definition (waste thickness and landfill bottom). The electrical profiling gives a better delineation of the waste disposal dimensions. 2D inversion surveys of electrical profiling show both lateral and vertical variations of the materials in the cross-section. Figure 4 presents two municipal solid waste trenches excavated on sandy geological substrate delineated by electrical Resistivity Method results (resistivity values lower than 20 ohm.m characterize the places filled with municipal solid waste).

Figure 5 shows the results of a survey performed in a contaminated site downstream from a landfill in Brazil. This site was investigated using a 3-D resistivity imaging technique. The purpose of this investigation was to detect and delineate the contamination plume produced by the waste and to acquire detailed information about the affected area. The data set consisted of a series of parallel electrical profile data acquired with the dipole-dipole arrangement, and was inverted as a complete 3-D survey. The resistivity model identifies the disposed waste and the contaminant, marked by the isosurface values lower than 20 ohm.m. The results indicate the presence of a contamination plume and its preferred path. Monitoring wells were installed in the affected area and their chemical analysis confirmed the influence of contaminants. 
Field Curve - VES 2

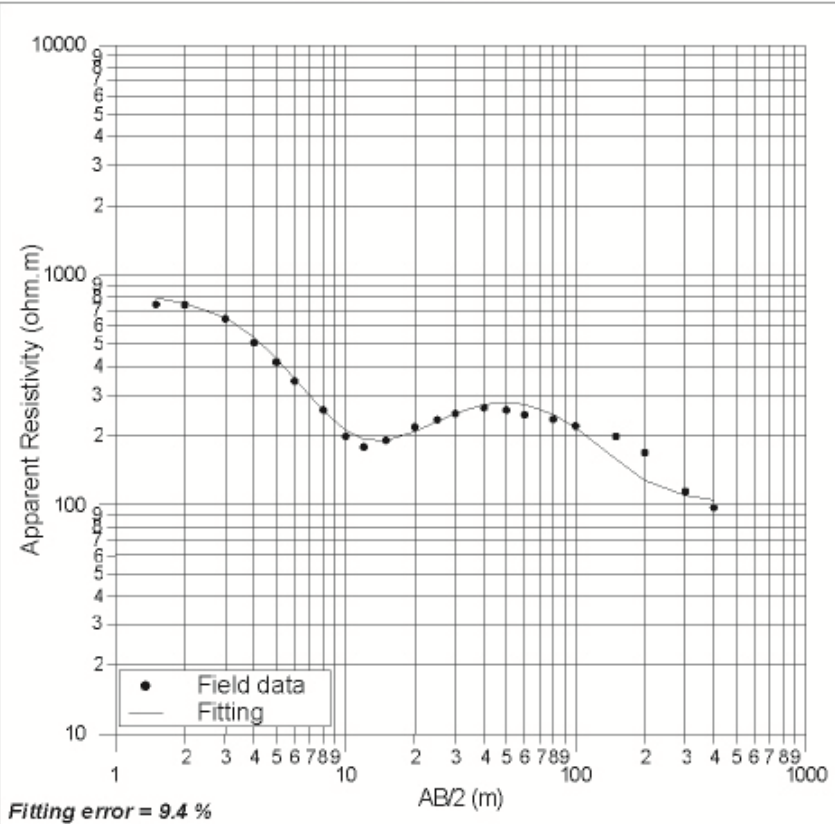

Geoelectrical Column

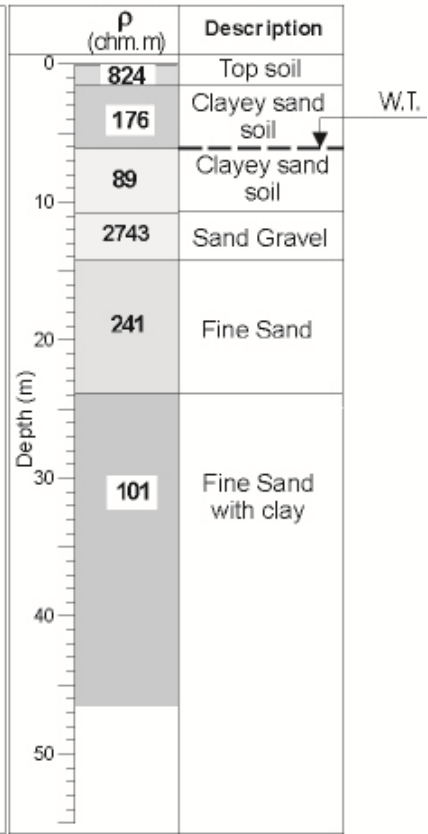

Fig. 3. Results of VES for studying the stratigraphic profile and position of the saturated zone (W.T.).

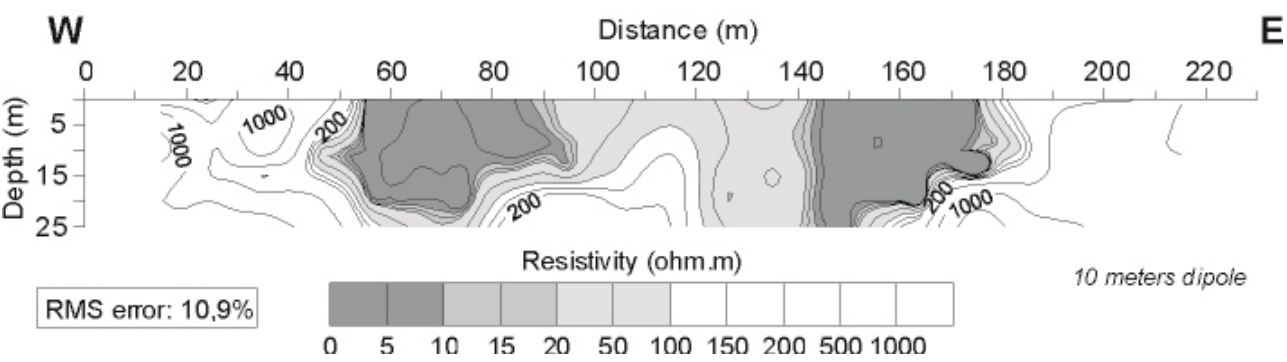

Fig. 4. Resistivity cross-section of waste disposal area. Lower resistivity zones characterize two trenches filled with municipal solid waste.

\subsection{Low Frequency Electromagnetics (Ground Conductivity Meters)}

The Electromagnetic Methods (EM) involves low frequency electromagnetic field propagation. When an alternating current $(\mathrm{AC})$ is established in a wire placed on the ground surface, electrical currents flow in subsurface conductors. This process is known as electromagnetic induction and constitutes the basis of the operation of low frequency electromagnetic methods. 
This method is very fast and it uses simple equipment easily operated. It explains the extensive application of this method for geo-environmental studies. The equipment used can be generally called ground conductivity meters. It consists of two coils (transmitter and receiver). The transmitter coil emits a primary magnetic field $H_{p}$, which induces electrical currents on the subsurface, generating a secondary magnetic field $H_{s}$ (Figure 6). The combination of these two fields is measured by the receiver coil. Under certain conditions it is known that there is a linear relationship between the modules of the two fields (McNeil, 1980), technically defined as "low induction number operation". Accordingly, the apparent conductivity can be calculated by $\sigma_{a}$ :

$$
\sigma_{a}=\frac{4}{\varpi \mu_{0} s^{2}}\left(\frac{H_{s}}{H_{p}}\right) \quad(\mathrm{mS} / \mathrm{m})
$$

where $\omega=$ angular frequency, $2 \pi f ; \mu_{0}=$ vacuum magnetic permeability; $s=$ intercoil spacing.

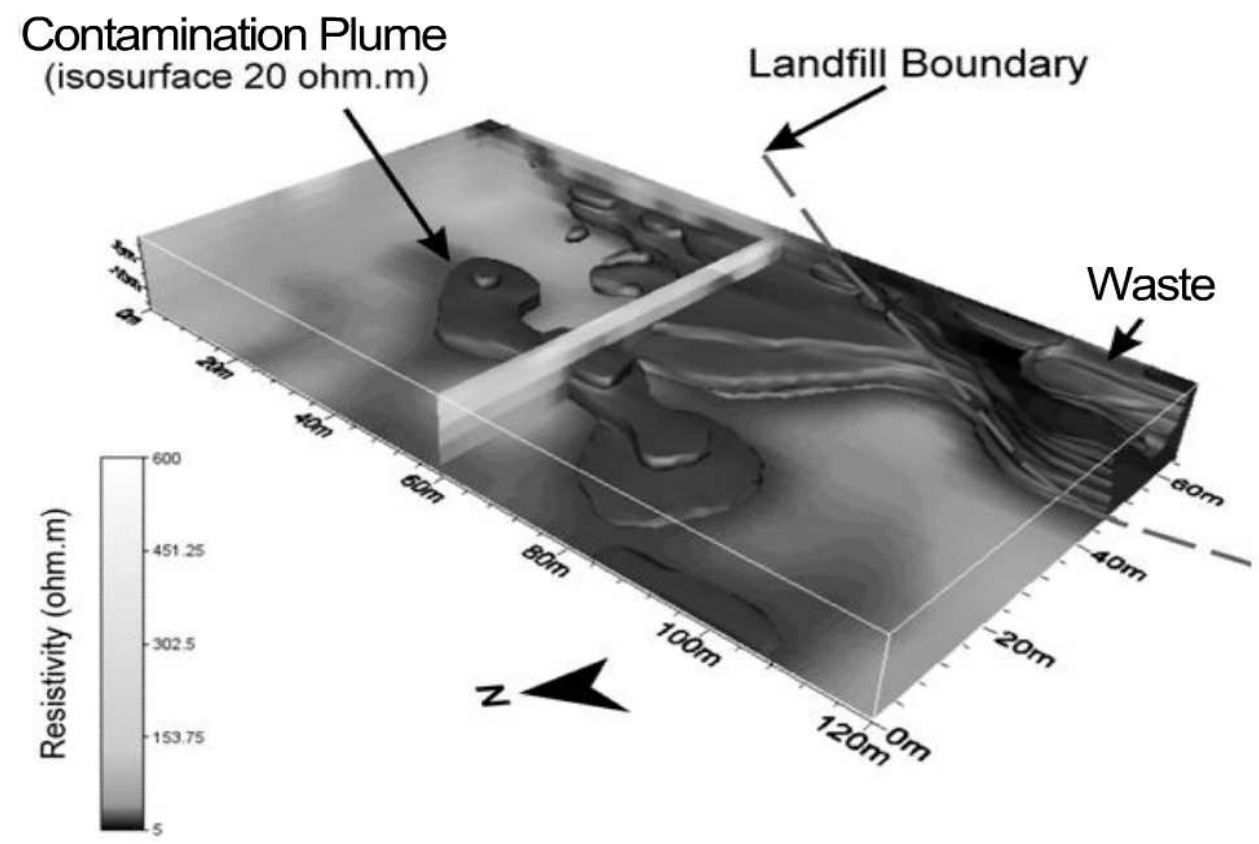

Fig. 5. 3D resistivity model of a contaminant plume generated by a municipal solid waste disposal site. The isosurface of $20 \mathrm{ohm} . \mathrm{m}$ delineates the contaminant plume, which is moving in a northwest direction.

The equipment is built to allow a direct reading of the apparent conductivity. The most commonly used equipment at present time was designed to explore pre-defined depths, between 7.5 to 60.0 meters, depending on the coils orientation (vertical loop and horizontal loop modes), the operating frequency and the intercoil spacing. The field tests are usually 
conducted in profiles, which, due to convenience of operation and transportation of the equipment, are carried out very quickly. The apparent conductivity data can be plotted on several profiles and depending on the distance, a set of profiles can form a site map. The interpretation of these data is basically qualitative, but nowadays there is inversion software designed for quantitative interpretation of conductivity profiling data (Monteiro Santos, 2004).

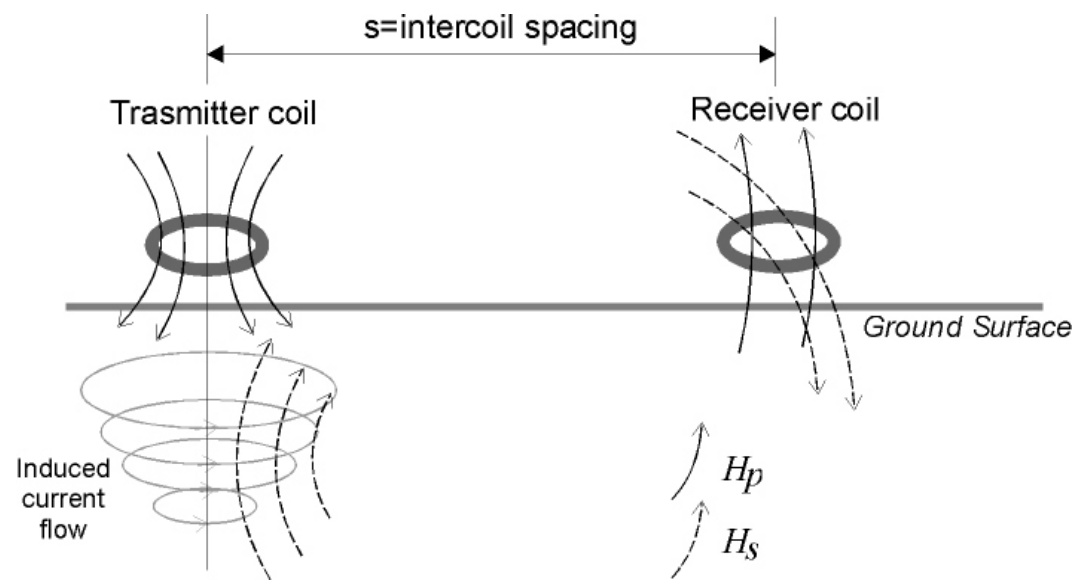

Fig. 6. Operating principle of the Ground Conductivity Meter.

The method is a cost effective and low time-consuming tool for investigating contamination generated by waste disposal sites, and allows delineation of the area affected by contaminants. Figure 7 shows the mapped out area of the contamination plume delineation, which has been created by a municipal solid waste disposal site. The MSW boundaries are marked in a broken white line (black points are measurement stations). The northwestern part of the landfill presents low electrical conductivity, characterizing a granitic base. The site is occupied by waste deposited onto tertiary stream sediments, and the groundwater level appears at around 5 meters depth. The contours of the waste disposed at the site can be identified based on the values of apparent electrical conductivity higher than $50 \mathrm{mS} / \mathrm{m}$. The contamination plume can also be observed in this figure, which flows to the West, marked by high values of apparent conductivity outside of the waste filled area.

\section{Invasive tests}

In some particular sites it is difficult to identify the subsoil properties contrasts based only on geophysical data or index properties, especially in a very heterogeneous municipal solid waste (MSW) disposal site on unsaturated tropical soils. The proper site investigation in these sites relies on invasive tests, including soil, groundwater and direct gas sampling.

The modern approach for geo-environmental site characterization using invasive tests relies on the piezocone technology. The piezocone and it accessories are used as a screening tool for stratigraphic logging of geotechnical and chemical measurements. This approach often allows identifying potentially critical zones which may require more specific tests to measure or monitor contaminants based on specific sampling and/or monitoring. 


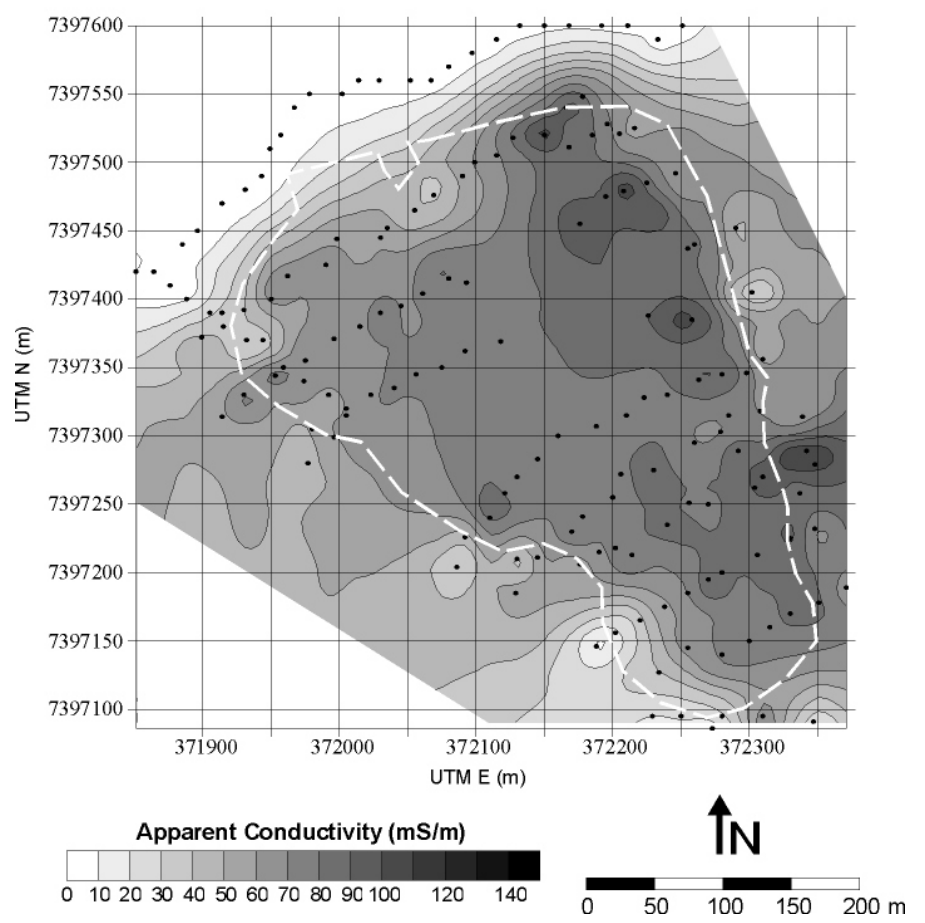

Fig. 7. Apparent conductivity map of a waste disposal site. Theoretical depth of exploration is 7.5 meters. The broken white line marks the limits of the deposit. Note the good match of the boundaries of the deposit with the high apparent conductivity values $(>50 \mathrm{mS} / \mathrm{m})$.

\subsection{Piezocone test and accessories}

\subsubsection{The piezocone}

Piezocone penetration test (CPTU) is a standard site investigation tool currently used for geotechnical site characterization (Lunne et al, 1997). According to Shinn II \& Bratton (1995), the heart of a modern site characterization approach uses the piezocone penetration test. The CPTU test uses a standard instrument probe (ASTM D 5778-07) with a $60^{\circ}$ apex and typically $35.68 \mathrm{~mm}$ diameter $\left(10 \mathrm{~cm}^{2}\right.$ area) fitted on the end of a series of rods (Figure 8 ). The probe is pushed into the ground at an approximate constant rate of $2 \mathrm{~cm} / \mathrm{sec}$ by a hydraulic pushing source, such as a standard drill rig or cone pushing vehicle. As the cone is advanced, the forces measured by the tip and friction sleeve will vary with the material properties of the soil being penetrated. Tip resistance $\left(q_{c}\right)$, friction sleeve stress $\left(f_{s}\right)$ and dynamic pore-pressure (U) response are measured by calibrated electrical instruments. All channels are continuously monitored and typically digitized at 10, 20, 25 or $50 \mathrm{~mm}$ intervals.

\subsubsection{Piezocone data and interpretation}

Piezocone test data is gathered by a computer which allows the user to carry out straightforward post-investigative analysis. The three parameters $\left(q_{c}, R_{f}\right.$ and $\left.U\right)$ in various 
combinations, such as friction ratio $\left(\mathrm{R}_{\mathrm{f}}=\left(\mathrm{f}_{\mathrm{s}} / \mathrm{q}_{\mathrm{c}}\right) 100 \%\right)$, are used to delineate site stratigraphy by using soil classification charts, as proposed by Robertson et al. (1986) and presented in Figure 9. Empirical and semi-theoretical correlations are available in relevant literature in order to estimate mechanical properties of the soil.

Measurement of equilibrium pore pressure at full pore pressure dissipation allows quantifying the vertical hydraulic gradients by using a single sounding and groundwater flow regime, whenever multiple soundings are available. The pore pressure dissipation test also allows estimation of hydraulic conductivity (Campanella, 2008).

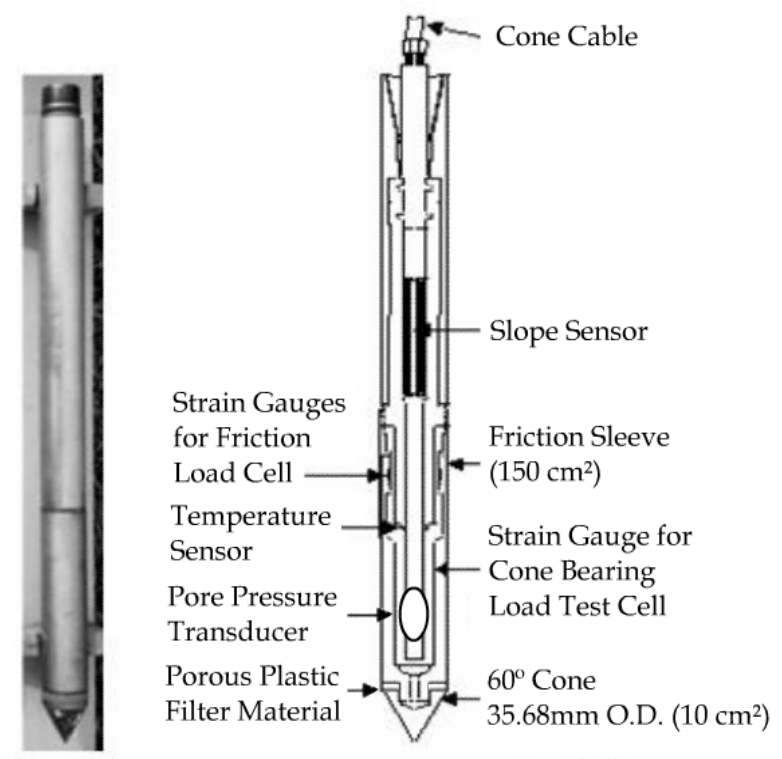

Fig. 8. Schematic drawing and photo of a piezocone probe (modified from Davies \& Campanella, 1995).

\subsubsection{Accessories}

As pointed out by US EPA (1989), a geo-environmental site characterization requires information on the chemical distribution and sources (s)/receptor(s) for potential or existing contaminants. The piezocone technology for geo-environmental application included specific sensors for temperature, resistivity, $\mathrm{pH}$, laser-induced fluorescence, among others. This technology also includes samplers to be used together with the piezocone for sampling soils, water and gas (Lunne et al, 1997). Robertson \& Cabal (2008) present in details the main piezocone accessories available for geo-environmental site characterization.

The use of the piezocone test and accessories for geo-environmental applications essentially creates no cuttings, produces little disturbance, and reduces contact between field personnel and the contaminants, as the penetrometer push rods can be decontaminated during retrieval (Robertson, 1998). The major limitation of the piezocone test is the impossibility of carrying out the test in gravel. 


\subsubsection{Resistivity piezocone}

Resistivity is one of the piezocone accessories which is called the resistivity piezocone (RCPTU) test. It measures the electrical resistance of a current flow in the ground. This additional information is extremely useful due to the significant effects that dissolved and free product constituents have on bulk soil resistivity (Campanella, 2008).
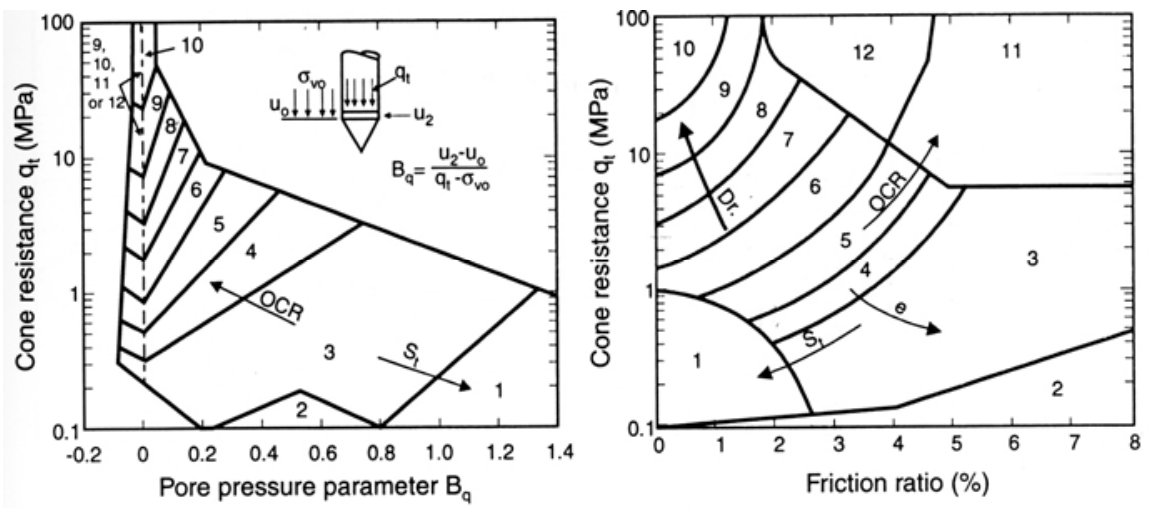

Zone: Soil Behaviour Type:

$\begin{array}{ll}\text { 1. } & \text { Sensitive fine grained } \\ \text { 2. } & \text { Organic material } \\ \text { 3. } & \text { Clay } \\ \text { 4. } & \text { Silty clay to clay }\end{array}$

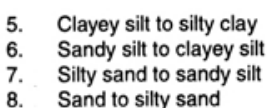

8. Sand to silty sand
9. Sand
10. Gravelly sand to sand
11. Very stiff fine grained*
12. Sand to clayey sand*

12. Sand to clayey sand ${ }^{*}$

Fig. 9. Piezocone soil behavior type charts proposed by Robertson et al (1986).

The preparations involved in the RCPTU test are similar to those of any other CPT test (Robertson \& Campanella, 1988). The only additional procedure is the connection of a signal generator to the data acquisition system for controlling the current level and frequency of the electrical resistance measurements. Weemees (1990) discusses the importance of working with alternating current and sufficiently high frequencies to prevent polarization of the external electrodes. A frequency of $1000 \mathrm{~Hz}$ is usually used.

Figure 10 presents a Wenner-type resistivity piezocone (RCPTU) with an array of four electrodes. Resistivity measurements are taken with the inner electrodes and the current is applied through outer electrodes. These measurements are digitally recorded at $25 \mathrm{~mm}$ intervals, providing essentially continuous in-situ data sampling in addition to all the other standard CPTU measurements.

Measurements of bulk resistivity trends indicate whether some dissolved or free product exists below or above the background values. The background values are usually established from RCPTU tests carried out on-site. According to Campanella (2008), the areas where readings are very different (anomalies) from the background values are then further evaluated with appropriate groundwater sampling at discrete depths for detailed chemical analysis. Considerable practical value is gained from the fact that the measured resistivity in saturated soil is almost totally governed by the pore fluid chemistry. 

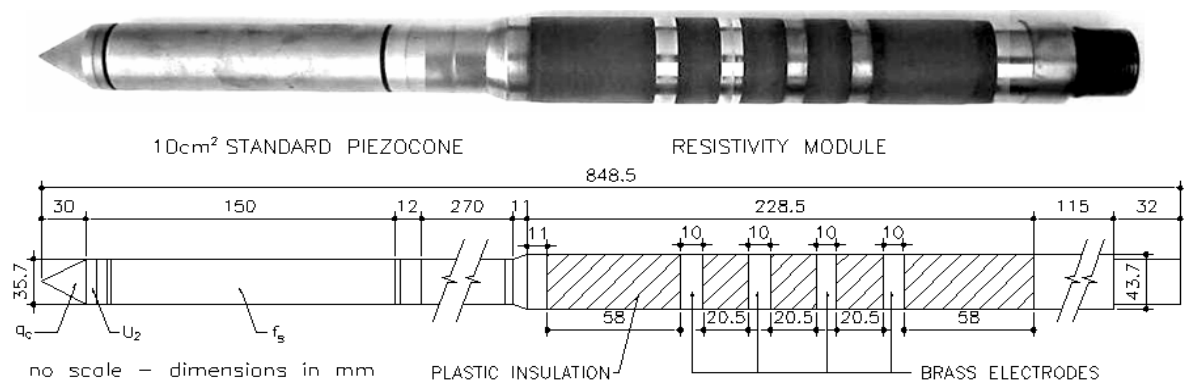

Fig. 10. Schematic representation and photo of a resistivity piezocone probe with a fourelectrode arrangement (Mondelli et al., 2007).

\subsection{Samplers}

A large number of samplers for gas, water and soil sampling have been developed for pushing into the ground using the same equipment that is used for the piezocone test. These samplers are designed for either one-time samples or as monitoring wells. Robertson \& Cabal (2008) describe in details some samplers available for geo-environmental site investigation and they will be briefly presented in the follow items.

\subsubsection{Soil sampling}

A wide variety of push-in discrete depth soil samplers are available and most of them are based on designs similar to the Gouda soil samplers. Robertson \& Cabal (2008) describe some soil samplers including the Gouda type sampler. It is pushed into the ground at the desired depth in a closed position and it has an inner cone tip that is retracted to the locked position leaving a hollow sampler with small diameter $(25 \mathrm{~mm})$ stainless steel or brass sample tubes. The hollow sampler is then pushed to collect a sample. The filled sampler and push rods are then retrieved to the ground level. Figure 11 shows a schematic drawing of a typical CPT based soil sampler (Gouda type), as described in detail by Robertson \& Cabal (2008).

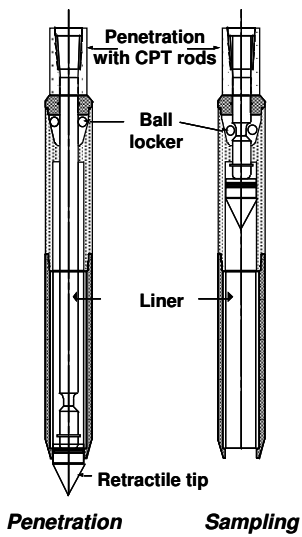

Fig. 11. Schematic drawing of a typical (Gouda type) CPT based soil sampler. 


\subsubsection{Water sampling}

Robertson \& Cabal (2008) affirm that the most common direct-push, discrete depth, in-situ water sampler is the Hydropunch and to a lesser extent, the BAT, Simulprobe and Waterloo Profiler. The Hydropunch sampler and its variations is a simple sampling tool that is pushed down to the desired depth and the push rods withdrawn to expose the filter screen and is described in detail by Robertson \& Cabal (2008). A modification of the commercially available BAT groundwater sampler is recommended by Campanella (2008) for obtaining in-situ pore fluid samples and it is presented in Figure 12. This author discribes the original BAT system, which consists of a sampling tip that is accessed through sterile evacuated glass sample tubes and a double-ended hypodermic needle set-up pushed through septum seals. The tube sampler is lowered either by cable or electrical wire depending upon whether a pore fluid sample is taken with or without a pressure test being carried out. Acording to Campanella (2008), the BAT probe is also able to take pore gas samples for collecting volatile contaminants.

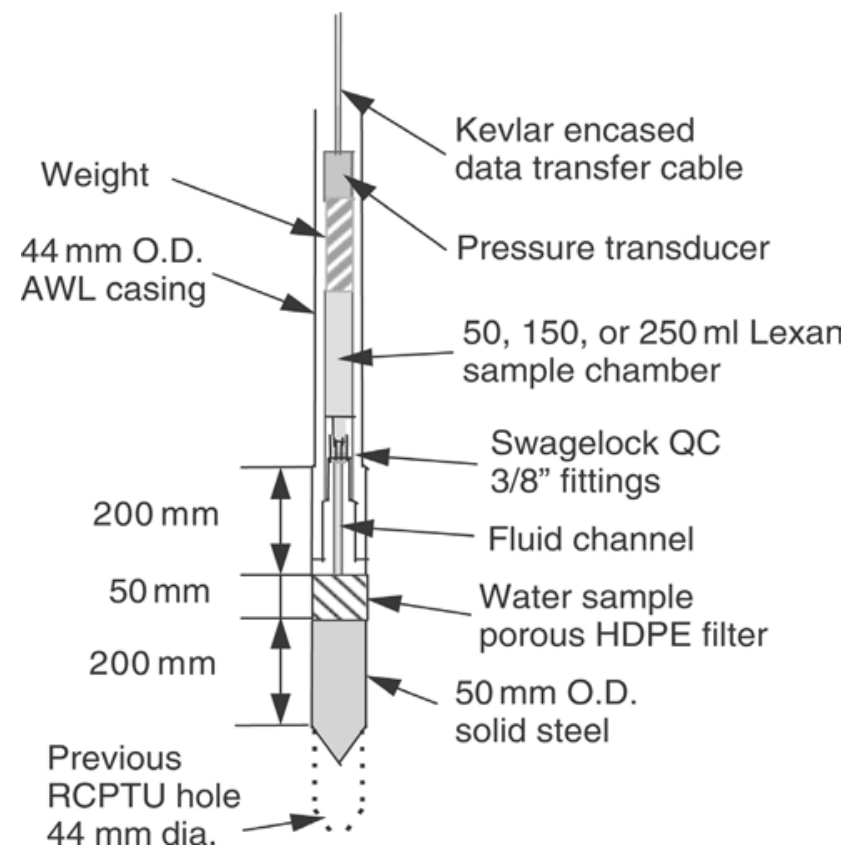

Fig. 12. UBC modified BAT groundwater sampler (Campanella, 2008).

\subsubsection{Gas sampling}

Gas samples can be collected in a similar way to the one previously described for groundwater samples. The most common gas sampler that uses the direct-push, discrete depth, in-situ method is the hydropunch type sampler. Robertson \& Cabal (2008) also describes this sampler in detail, which is pushed to the required depth, thus the filter element is exposed and a vacuum is applied to draw a vapor sample to the surface. Special disposable plastic tubing is used to draw the sample to the surface. 


\subsection{Example of using RCPTU test and samplers in a MSW disposal site}

An example of using the piezocone technology to assess contamination of a MSW disposal site from Brazil, by using different techniques is going to be briefly presented based on Mondelli's (2008) research. The site can be considered to be a controlled dump site because it is a planned landfill that incorporates some of the features of a sanitary landfill.

According to Mondelli et al. (2007), the site's geology has sandstone from the Adamantina and Marilia Formations, covered by alluvial sandy soils or colluvial clayey sands. Residual soils from sandstone are found underneath these layers. The hydraulic conductivity of the soil was found to vary from $10^{-7}$ to $10^{-6} \mathrm{~m} / \mathrm{s}$. The depth of the groundwater level is about 5 meters below the base of the landfill. In order to protect the subsurface and the shallow groundwater table from leakages from the landfill, four 20-cm-thick layers were compacted at the bottom of the landfill using local soil. The upper surface of these layers was coated twice with diluted asphalt emulsion to seal and protect the bottom of the landfill. This procedure was used because it was inexpensive and acceptable for controlled dumps in Brazil when this landfill was established.

This site was first investigated using a 3-D resistivity imaging technique, as described by Ustra et al. (2011). Several piezocone and resistivity piezocone tests were carried out on this site. In the first campaign, a four standard piezocone was carried out, measuring cone tip resistance $\left(\mathrm{q}_{\mathrm{c}}\right)$, sleeve friction $\left(\mathrm{f}_{\mathrm{s}}\right)$ and pore pressure $\left(\mathrm{u}_{2}\right)$. A resistivity piezocone was used in the other campaigns (16 tests). Pore pressure was recorded using a slot-filter filled with automotive grease in all the tests, as suggested by Larsson (1995).

A multifunction reaction system equipped with a hydraulic device with a capacity of $200 \mathrm{kN}$ was used to carry out the tests. Details of all the different tests carried out in this site are presented by Mondelli et al. (2007). Two piezocone tests were conducted at the highest parts of the landfill, to obtain a reference profile of the uncontaminated soil. However, resistance to cone penetration was greater than the capacity of the penetration system needed for reaching the groundwater level in this region, where residual soils and sandstone are shallower. Most of the RCPTU tests were performed downstream of the landfill, where sedimentary soils or more homogeneous tropical soils occur.

All the RCPTU tests that reached groundwater presented an abrupt reduction in resistivity. This information was useful to help identifying groundwater level (GWL). Two of the RCPTU test results are presented in Figure 13 and will be briefly discussed. The resistivity profiles shown in this figure for the saturated zone, indicate that the resistivity measurements are affected by soil texture and mineralogy. Mondelli et al. (2007) point out that the resistivity values were higher in sandy layers than in clayey layers. At that time the influence of soil type on the resistivity values of the RCPTU-14 and RCPTU-15 tests were not so clear, since the resistivity value found in the RCPTU-14 test was around $50 \mathrm{ohm} . \mathrm{m}$, while that of the RCPTU-15 test was around $20 \mathrm{ohm} . \mathrm{m}$ for saturated zone. It indicates a migration of the contamination plume through the sandy layer, based on water sampling using a direct-push sampler at depths of 8.0 to $9.0 \mathrm{~m}$, since it presented low electrical resistivity, which is indicative of the presence of contaminants dissolved in the water.

Mondelli et al. (2007) conclude that the RCPTU interpretation for this particular site required collection of soil and groundwater. It was also necessary to adapt a system to 
measure the electrical resistivity of undisturbed soil samples in the laboratory for better understanding the resistivity variation according to the different saturation conditions and lithological characteristics that occur in tropical regions. This system, as well as the test results, is presented by Mondelli et al. (2010a). The sampling depths were selected based on the interpretation of nearby piezocone and other tests.

Mondelli et al. (2010b) present in Figure 14 the relation between the resistivity values of the saturated layers and the results of the characterization tests on soil samples collected using a direct-push sampler, in order to allow identifying and visualizing the layers susceptible to contamination. These results indicate a tendency for increasing values of resistivity with decreasing fines content, clay content or with clay mineral activity. However, layers that do not clearly follow this tendency are also shown in Figure 13, presenting low values of resistivity (between 20 and $40 \mathrm{ohm} . \mathrm{m}$ ) for the sandier soils. These results demonstrate that values of resistivity ranging from 20 to $40 \mathrm{ohm}$.m for predominantly sandy layers indicate the presence of leachate in the groundwater.

This kind of interpretation goes beyond the merely comparative one of the resistivity values obtained from all the tests discussed by Mondelli et al. (2007), which had diagnosed the presence of contaminants only in tests RCPTU 14 and 15 presented in Figure 13. A certain degree of superposition of values may occur in this type of analysis, since the more clayey layers also show low values of resistivity. Since the flow of contaminants tends to occur between the sandier layers (more permeable), the problem can be simplified in an attempt to identify only these layers.
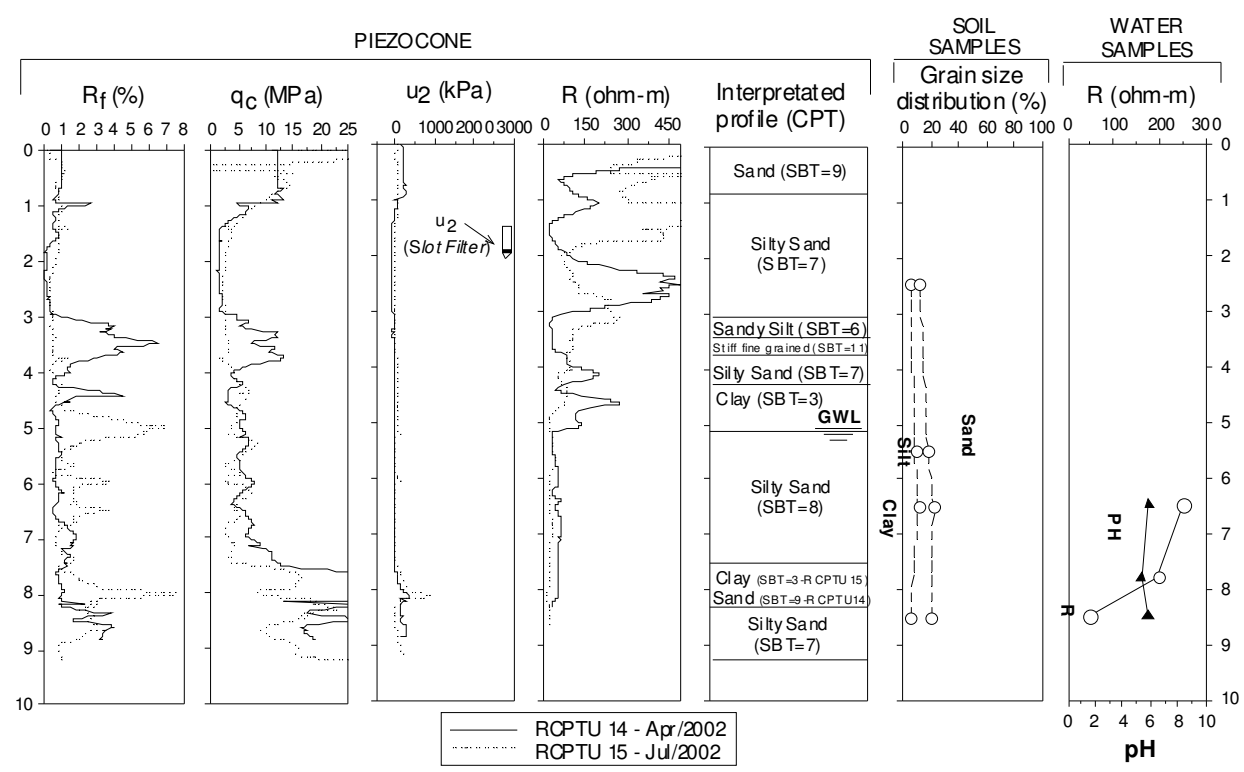

Fig. 13. RCPTU test results, grain size distribution and groundwater analyses for a MSW disposal site, adjacent to the edge of the landfill (Mondelli et al., 2007). 


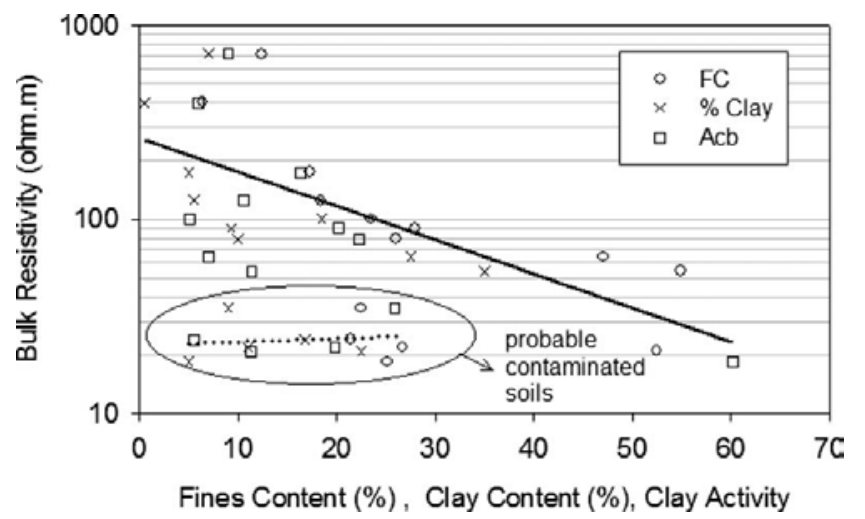

Fig. 14. Electrical resistivity in saturated soil samples with characterization of the fine fraction of soils for a MSW disposal site (Mondelli et al., 2010b).

Mondelli et al. (2010b) studies concluded that the resistivity piezocone test helped identifying contaminated zones. However, this technique presented some limitations for tropical soils, since the groundwater level is sometimes deeper than the penetrable capacity of the cone. The RCPTU tests were useful for detailing stratigraphic soil profile. The relation between corrected point resistance $\left(\mathrm{q}_{\mathrm{t}}\right)$ and friction ration $\left(\mathrm{R}_{\mathrm{f}}\right)$ allowed identifying the highly heterogeneous stratigraphic profiles of alluvium and colluvium. This identification for the residual soils was restricted to the behavior of the materials in response to the penetration of the piezocone, requiring soil sampling. The resistivity profiles were useful for the identification of the position of the groundwater level, and were sensitive to variations in the soil's texture and its saturation. A good relationship between the soil behavior index (Ic) and the fines content in the soil samples collected adjacent to the landfill helped the identification of contaminated regions of the saturated zone. The proper interpretation of piezocone tests enabled the identification of those layers more susceptible to contamination, which was confirmed by the chemical analyses of the groundwater samples collected from the monitoring wells. The main conclusion of this study is that the interpretation of RCPTU tests is not as straightforward as it is for sedimentary soils because the tropical soils genesis complexity.

\section{Laboratory tests for geo-environmental site characterization}

Laboratory tests can improve the interpretation of the in-situ test results, complementing, controlling and detailing the geo-environmental site investigation. A complete geoenvironmental site investigation using current engineering practice is usually difficult to carry out because it is expensive and normally requires authorization and multidisciplinary teams. In addition, an appropriate testing campaign is time consuming and only a few private companies can do it. Limited publications on monitoring and modeling of the contamination plume caused by MSW disposal sites are available. The most commonly known case histories (Cherry et al., 1983; MacFarlane et al., 1983; Mackay et al., 1986; Kjeldsen et al., 1998; Zuquette et al., 2005) have installed more than a hundred monitoring wells, with multilevel soil and groundwater sampling, and are taken from the same sites which have been studied for years. All these studies show that geophysical tests were carried out before the intrusive tests, which were also performed to confirm contamination. 
Christensen et al. (2000) explain that, contrary to the specific and known sources of contamination, - such as leaking fuel tanks (hydrocarbons) and chlorinated solvents - the municipal solid waste disposal sites are large, heterogeneous and receive various types of waste over time, have different flow pathways, hydraulic gradients and contamination plumes. Moreover, the size of the landfills will often prohibit removal of the waste and source of the leachate, suggesting that the landfill body and the leachate plume should be considered as a continuum in the context of natural attenuation.

In Brazil, most of the laboratory tests for sanitary landfills are preventive, for bottom or cover liner design, using low permeability compacted tropical soils with or without flexible membrane liners (Ritter, 1998; Boscov et al., 2001; Leite \& Paraguassú, 2002; Stuermer, 2005; Azevedo et al., 2006). This approach does not consider the older waste deposits, where the contaminants are in direct contact with the natural subsoil. In Brazil, there are some researches on geo-environmental site investigation of industrial and municipal solid wastes disposal sites, using geophysics or boreholes to detect contamination plumes (Grazinolli et al., 1999; Elis \& Zuquette, 2002; Lago et al., 2003; Anirban et al., 2004; Bolinelli Jr., 2004; Porsani et al., 2004;).

The in-situ techniques permit assessing the natural conditions of the soils, while the laboratory tests provide greater detail, but in minor scale, trying to represent the field conditions based on soil and water/gas samplings. Those difficulties in defining a typical soil profile, hydrogeological parameters and background resistivity (or conductivity) values due to geological complexity (like tropical sites, for example) demand more and varied site investigation techniques. After a better understanding of the site history, topography, hydrogeology and the landfill construction characteristics, laboratory tests can be carried out using disturbed and undisturbed soil samples, in order to investigate a new site for the installation of a sanitary landfill, or to confirm a pre-indicated contamination or to provide support for future remediation actions.

The typical soil profile, hydrogeological characteristics and background values can be confirmed and obtained also using laboratory tests. The soil can be characterized using geotechnical, geochemical and mineralogical techniques. Batch sorption and column leaching tests can be carried out using those geomaterials found at the study site. The landfill's leachate can be used to estimate the dispersion and retardation coefficients, for future contamination flow transport modeling. Electrical resistivity values and mineralogical constituents of non-contaminated soils can be determined in the laboratory.

\subsection{Soil characterization}

The characterization tests are fundamental for the classification of soils, due to their complex geological formation, and even more when performing a geo-environmental site investigation, where the interaction between the contaminants and the physical environment usually occurs. The more usual laboratory characterization tests to investigate a municipal solid waste disposal sites are:

- Geotechnical Properties (Lambe \& Whitman, 1969): classical laboratory tests for physical soil characterization are essential for geo-environmental site investigation. Indexes like in-situ moisture content $(w)$, natural unit weight $(\gamma)$, specific gravity (Gs), grain size distribution with and without sodium hexametaphosphate for determination of clay, 
silt, sand and gravel contents, liquid limit (LL) and plastic limit (PL), shall be determined using disturbed and undisturbed soil samples. Also, permeability / hydraulic conductivity $(\mathrm{K})$ tests are necessary for a good monitoring and pollution prevention of a waste disposal site or for future sanitary landfill, respectively. Depending on the groundwater position and the characteristics of the site, tests to determine the soil retention curve can also be important in a site investigation and monitoring program.

- Organic Matter Content (OMC): OMC is considered an important property of the soil solid phase, as it is responsible for retaining a good part of the organic contaminants and leachate ions, together with clay minerals and hydroxides. OMC can be determined by incineration of the soil sample in a muffle, heating to temperature of $440^{\circ} \mathrm{C}$, as described in ABNT NBR 13600 (1996).

- Blue Methyl Adsorption: this test allows the estimative of the cation exchange capacity (CEC), specific soil surface (SE) and activity of clay minerals. This test also indicates the predominant type of clay mineral matrix in fines content of the soil sample. Lan (1977) and Pejon (1992) describe this test method in detail.

- X-Ray Diffraction (XRD), Differential Thermal Analysis (DTA) and Gravimetrical Thermal Analysis (GTA): These tests allow characterization of the soil fines content, by heating up the soil sample to $1000^{\circ} \mathrm{C}$, in order to identify and quantify different clay minerals, hydroxides and any solid constituent of the soil. Consequently, the tests can be used to identify the soil mineralogy and its geochemical interaction with the landfill, or for assessing natural attenuation of the contaminants.

- $\quad p H$ : Determination of $\mathrm{pH}$ of granular materials in deionized water (usually ratio of 1 : 2.5), by measurement of the effective electrochemical concentration of $\mathrm{H}^{+}$ions in soil solution or waste using a combined electrode immersed in suspension. The test method is that one recommended by US EPA (1993).

- $\quad X$-Ray Fluorescence (XRF): XRF spectrometry is used to identify elements in a soil and quantify the amount of those elements (metals) present. An element is identified by its characteristic X-ray emission wavelength $(\lambda)$ or energy (E). The amount of an element present is quantified by measuring the intensity of its characteristic line. It is known that original rock composition can or cannot present natural high concentrations of some metals. For geo-environmental purposes, these conditions cannot exceed safety, health or potability exigencies for the local population. Therefore, it is noted that the levels of these metals in soils and sediments depend on the composition and proportion of them in their original solid phase. The background values need to be diagnosed before or after the waste disposal. Innov-X Systems Alpha Series (2007) presents handheld EDXRF spectrometers, ideally suited for field and laboratory analysis of soil and waste metals.

As example, Figure 15 presents a typical soil profile, characterized for construction of a future waste disposal site for a very small city in the interior of the São Paulo State, Brazil. IPT (2011) carried out a low cost geo-environmental site investigation campaign with the objective of detecting possible contamination caused by an older controlled dump near to the interest site.

The results presented in Figure 15 shows the log of the number of blows from Standard Penetration Test $\left(\mathrm{N}_{\mathrm{SPT}}\right)$ up to $16.5 \mathrm{~m}$ depth, when the impenetrable layer was reached. During the SPT tests, deformed soil samples were collected, in order to maintain the natural 
moisture, and were transported to the laboratory. In the laboratory soil samples were identified based on tactile visual inspection. So, "new" soil samples were composed using the same lythology. The collected soil samples were characterized, determining moisture content $(\mathrm{w})$, organic matter content $(\mathrm{OMC}), \mathrm{pH}$, electrical conductivity, grain size distribution and XRF analysis using an Innov-X handheld EDXRF spectrometer.

Figure 15 shows that the soil profile is formed by a very loose to loose sand, up to about 9.5 $\mathrm{m}$ depth. Between 9.5 and $13.0 \mathrm{~m}$ the subsoil has a medium compacity $\left(9<\mathrm{N}_{\mathrm{SPT}}<18\right)$, when a layer of the same grain size is reached, but coarser and more compacted, presenting $\mathrm{N}_{\mathrm{SPT}}>$ 20. Residual soil from sandstone was found below $15.0 \mathrm{~m}$ depth. The moisture content was around $7-8 \%$, which changed just when the groundwater level was reached, at $13.0 \mathrm{~m}$ depth, increasing to $17 \%$.

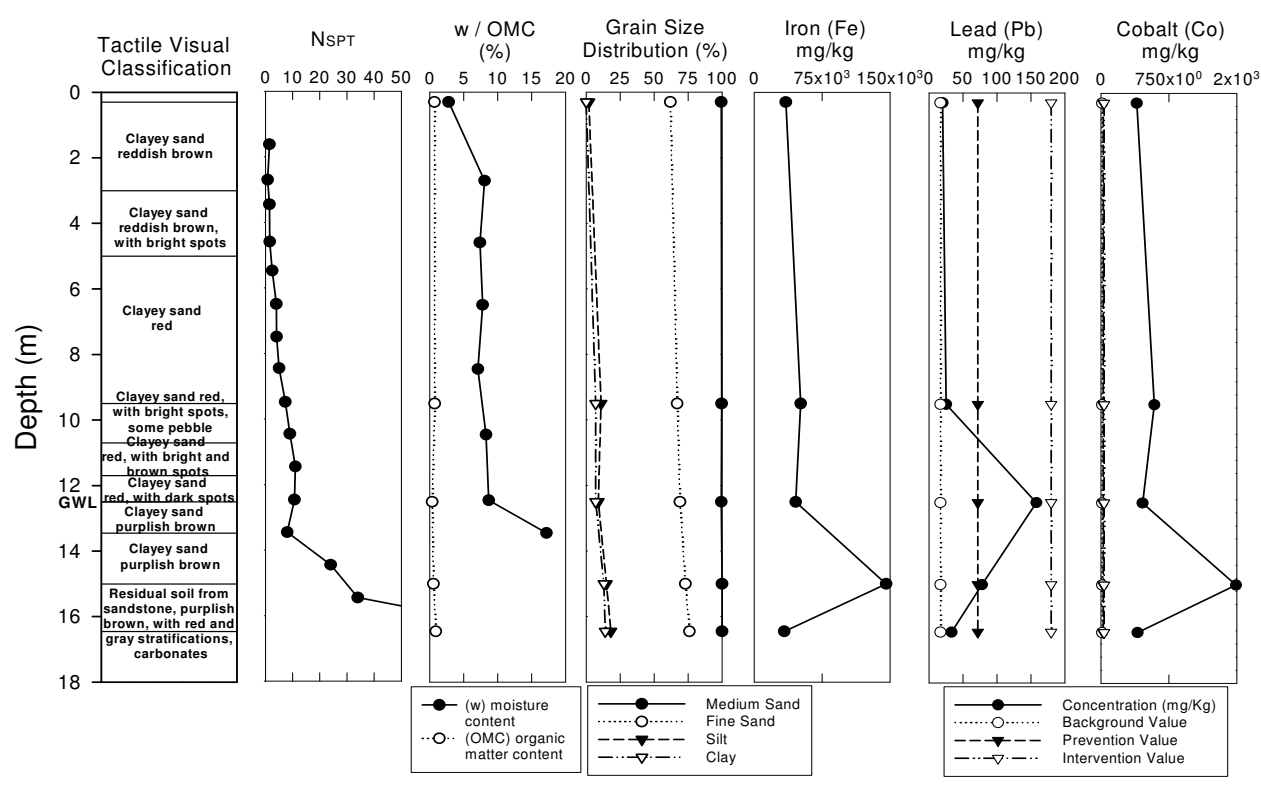

Fig. 15. Soil characterization profiles for a geo-environmental site investigation to install future sanitary trenches in a small city from Brazil.

The local soil is basically constituted of a fine to medium sand. Clay content tends to increase with depth, ranging from 0 to $16 \%$. The organic matter content was found to be very low, ranging between 0.7 and $0.9 \%$, tending to decrease to 0.3 to $0.4 \%$, for the residual soil from sandstone.

The geochemical profiles obtained for iron, cobalt and lead are also presented in Figure 15. They have to be compared with the background, prevention and intervention values determined for agricultural use by the Environmental Company from São Paulo State (CETESB, 2005). There is no reference value published for iron in the São Paulo State, Brazil. It is observed that all parameters have reached peak concentrations when residual soil from sandstone is encountered. The cobalt value is greater than the intervention value and lead levels are greater than the reference value throughout all the subsoil profiling. The lead level 
is also greater than the intervention value for the residual soil. These high levels of $\mathrm{Co}, \mathrm{Pb}$ and $\mathrm{Fe}$ may be associated with the constitution of the natural bedrock and in the case of where iron, iron oxides and hydroxides appear, they work like a cementing constituent for the quartz particles. The electrical conductivity (EC) values measured for the local soil were very low, ranging between 10.4 and $18.0 \mu \mathrm{S} / \mathrm{cm}$, indicating that the soil is in its natural state, without ever coming into contact with leachate (highly conductive) from the older existing waste dump.

\subsection{Electrical resistivity}

In order to assess the changes in the resistivity values with the degree of saturation, contamination and mineralogy of some typical geomaterials found at waste disposal sites, undisturbed soil samples and leachate can be carefully selected and sampled around a particular site, for a controlled and detailed study in the laboratory, in order to interpret the in-situ resistivity maps and profiles obtained during geophysical campaigns.

Mondelli et al. (2010a) present laboratory electrical resistivity measurements to detect the contamination plumes surrounding and below a waste deposit. These authors measured electrical resistivity $(\mathrm{R})$ of natural undisturbed samples as well as specimens saturated with distilled water, salt solution and original leachate from a MSW disposal site. While the specimens were naturally air dried during a specific period, the resistivity and the degree of saturation were measured. The system consists of an insulating material (PVC) mold, with two stainless-steel cylindrical electrodes, one on the top and another on the bottom of the specimen for electrical current measurement, similar to the one developed by Daniel (1997). Two more 3 $\mathrm{mm}$ diameter stainless-steel electrodes were attached into the middle of the specimen, observing the same distance between them (Wenner array) for differential potential transfer. For data acquisition, a Syscal Pro equipment was used. Figure 16 presents the apparatus used.
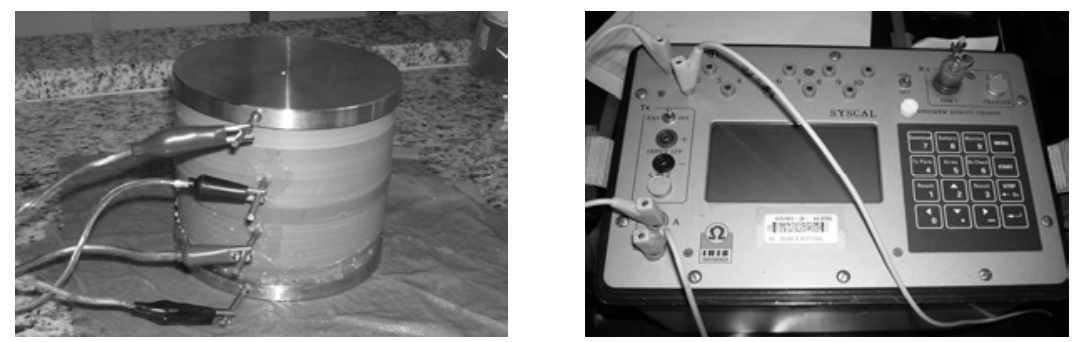

Fig. 16. Instrumented undisturbed specimen and Syscal Pro equipment used for laboratory electrical resistivity measurements (Mondelli et al., 2010a).

Mondelli et al. (2010a) concluded that the laboratory test results supported the interpretation of the in-situ test data, identifying the contamination spots, plume depths, capillarity and saturation zones and the different types of local soil. The results demonstrated the high influence of mineralogy and degree of weathering of the tropical soils on electrical resistivity values, also suggesting reference values for the study site. Figure 17 presents the results obtained for samples percolated with leachate $(\mathrm{EC}=25,000 \mu \mathrm{S} / \mathrm{cm}$ and $\mathrm{R}=0.4 \mathrm{ohm} . \mathrm{m})$. At the beginning of the test, the resistivity values did not exceed $10 \mathrm{ohm} . \mathrm{m}$ until a $50 \%$ degree of saturation was achieved. Below this degree of saturation, resistivity increased exponentially. 
Due to the high electrical conductivity of the leachate, the resistivity values became very low, with no influence of mineralogy in this case. These results could be interpreted using Archie's Law (Archie, 1942), as studied by Mondelli (2008).

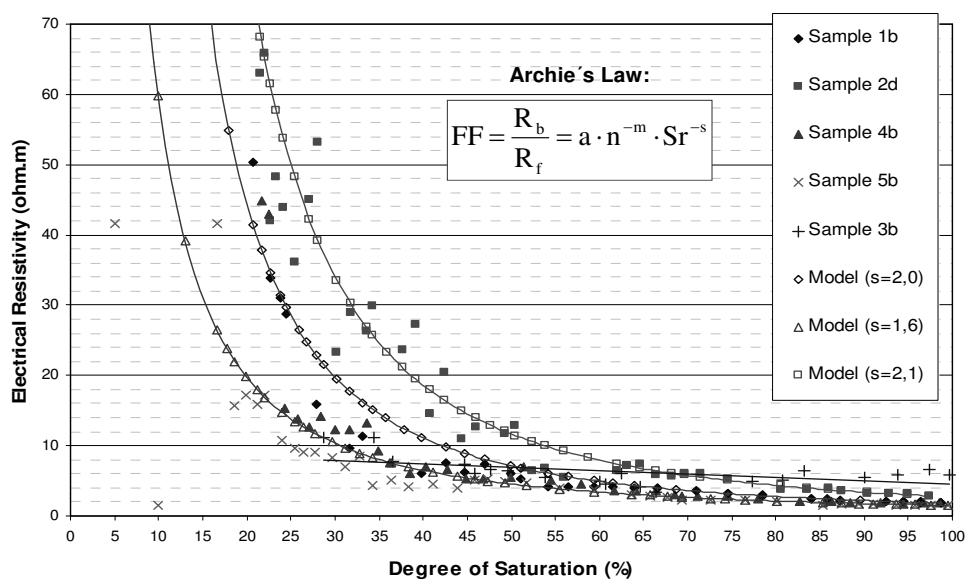

Fig. 17. Electrical resistivity versus degree of saturation for different soil samples percolated with the leachate from a MSW disposal site from Brazil (Mondelli, 2008).

\subsection{Pollutant transport parameters}

Estimates of pollutant transport parameters based on laboratory tests such as column, diffusion and batch equilibrium tests are also important in the more detailed phases of geoenvironmental investigations (Freeze \& Cherry, 1979; Rowe et al., 1988; Barone et al., 1989; Shackelford \& Daniel, 1991; Yong et al., 1992; Shackelford, 1993; ong, 2001). These laboratory tests can be conducted with the objective of a better interpretation of the in-situ test results, and for a numerical modeling performance, using a good conceptual model definition for the problem. Compacted or undisturbed soil samples can be used to assess the pollutant transport parameters, targeting the contamination plume behavior when in contact with the natural environment, using equipment and methods which allows the study of the anisotropy, degree of saturation and chemical extraction.

When the determination of pollutant transport parameters is being planned, one of the most important aspects to be defined is the interest pollutants or solutions to be used during the laboratory tests. For geo-environmental investigation of MSW disposal sites, original or artificial leachate can be used. The detection of a concentration of several constituents of leachate (like heavy metals, metals, chloride, organic compounds, chemical oxygen demand and biological oxygen demand), solutions and effluents collected during the tests, need to be chemically analyzed, using emission or atomic absorption spectrometers, flame photometry, chromatography and any other appropriate techniques. The preparation and preservation proceeds to detect any kind of chemical compound need to follow the standards described in APHA, AWWA, WEF (1995).

The laboratory apparatus for column tests also needs to be planned, depending on the sample state (compacted or undisturbed), the hydraulic gradients involved defined in 
accordance with the field conditions and if the column system will use rigid or flexible wall permeameters. All components of the apparatus were made of non-reactive materials. This test estimates the hydraulic conductivity $(\mathrm{k})$, hydrodynamic dispersion coefficient $\left(\mathrm{D}_{\mathrm{hl}}\right)$ and retardation factor $\left(R_{d}\right)$, due to pollutant solutions or leachate percolation through the soil sample. Once the breakthrough curves (relation between solute concentration and initial concentration $-\mathrm{C} / \mathrm{C}_{0}$ in function of the soil pore volumes percolated with the pollutant solution - T) are obtained for each interest solute, considering predominantly advective transport, the hydrodynamic dispersion coefficient $\left(\mathrm{D}_{\mathrm{hl}}\right)$ and the retardation factor $\left(\mathrm{R}_{\mathrm{d}}\right)$ can be assessed using the following equation proposed by Shackelford (1994):

$$
\frac{\mathrm{C}}{\mathrm{C}_{0}}=\frac{1}{2}\left\{\operatorname{erfc}\left[\frac{1-\left(\mathrm{T} / \mathrm{R}_{\mathrm{d}}\right)}{2 \sqrt{\frac{\left(\mathrm{t} / \mathrm{R}_{\mathrm{d}}\right)}{(\mathrm{uL}) / \mathrm{D}_{\mathrm{h}}}}}\right]+\exp \left[\frac{\mathrm{vL}}{\mathrm{D}_{\mathrm{h}}}\right] \operatorname{erfc}\left[\frac{1+\left(\mathrm{T} / \mathrm{R}_{\mathrm{d}}\right)}{2 \sqrt{\frac{\left(\mathrm{t} / \mathrm{R}_{\mathrm{d}}\right)}{(\mathrm{uL}) / \mathrm{D}_{\mathrm{h}}}}}\right]\right\}
$$

where: $\mathrm{t}=$ test time; $\mathrm{T}=$ time factor or soil pore volumes percolated with the pollutant solution; $\mathrm{u}=$ Darcy'Law specific velocity; $\mathrm{L}=$ height of the specimen; $\left(\mathrm{uL} / \mathrm{D}_{\mathrm{h}}\right)=$ Peclet number.

For non-misceble and reactive solutes, the retardation factor $\left(\mathrm{R}_{\mathrm{d}}\right)$ can be obtained from batch sorption tests. This test can be carried out following ASTM D 4646-03 and ASTM C 1733-10, standards, using a previously defined soil-solution ratio, as 1:4 (25 g of dry soil sieved through a 40 mesh to $100 \mathrm{~mL}$ of leachate or pollutant solution). $R_{d}$ is given by equation 5 :

$$
\mathrm{R}_{\mathrm{d}}=1+\frac{\rho_{\mathrm{d}}}{\mathrm{n}} \cdot \mathrm{K}_{\mathrm{d}}
$$

where: $\rho_{d}=$ soil specific dried mass; $\mathrm{n}=$ soil porosity; $\mathrm{K}_{\mathrm{d}}=$ partition coefficient.

Partition coefficient $\left(K_{d}\right)$ represents the angular coefficient of the linear sorption isotherm, defined for an interest solute, during batch sorption tests. For the construction of the sorption isotherms, the amount of soil or solute concentration in the solution can change. When original leachate is used during the test, the solute concentrations remain constant. After a previously determined equilibrium time, the supernatants are filtered, adequatly preserved and stored at $4^{\circ} \mathrm{C}$ until the chemical analysis, for a limited time, depending on the interest solute. The results are expressed as the adsorption degree, as a function of the concentration. The adsorption degree $(S)$ is defined by the following equation:

$$
\mathrm{S}=\frac{\left(\mathrm{C}_{0}-\mathrm{C}_{\mathrm{e}}\right) \cdot \mathrm{V}}{\mathrm{M}}
$$

where: $\mathrm{C}_{0}=$ initial concentration of the solution; $\mathrm{C}_{\mathrm{e}}=$ equilibrium concentration; $\mathrm{V}=$ volume of the solution in the flask; $\mathrm{M}=$ dry soil mass.

Frempong \& Yanful (2008) and Mondelli (2008) studied the sorption capacity of tropical soils from Ghana (West Africa) and São Paulo State (Brazil), using original leachate from local MSW disposal sites, and batch and column tests. Both these studies showed the following ion sorption selectivity order: $\mathrm{Ca}^{2+}<\mathrm{Cl}^{-}<\mathrm{Na}^{+} \leq \mathrm{Br}^{-}<\mathrm{Zn}^{2+}<\mathrm{Fe}^{2}<\mathrm{K}^{+}$. A significant finding from these studies is the observation that kaolinite and aluminum and iron oxyhydroxides with variable particle surface charges present in the soil allowed sorption of 
anions, such as $\mathrm{Cl}^{-}$and $\mathrm{Br}$-, generally considered conservative nonreactive, based on leachate-liner compatibility studies on soils from temperate regions.

Frempong \& Yanful (2008) found $\mathrm{R}_{\mathrm{d}}$ ranging from 1.1 to 47.9 for $\mathrm{Na}, \mathrm{K}, \mathrm{Br}$ and $\mathrm{Cl}$ for clayey tropical soils. Mondelli (2008) found major values of $\mathrm{R}_{\mathrm{d}}$, ranging from 1 to 383 for $\mathrm{Na}, \mathrm{K}, \mathrm{Fe}$ and Zn for sandy tropical soils, with $20 \%$ of clay content. Ritter (1998) classified the solute as essentially immobile when $K_{d}$ is higher than 10 . On the other hand, $R_{d}$ values display the same order of magnitude as those obtained by Nascentes (2003) with similar soil and range of tested concentrations. Azevedo et al. (2003) point out that the high $R_{d}$ values obtained by Nascentes (2003) can be the result of the low concentrations of metals used in the pollutant solutions. Figure 19 presents the sorption isotherm obtained for potassium (K) by Mondelli (2008), indicating that adsorption degree (S) increases along with the increase in equilibrium concentration $\left(\mathrm{C}_{\mathrm{e}}\right)$. In this case, the linear isotherm was the one that best described the results, presenting a better fit to the testing data and $\mathrm{K}_{\mathrm{d}}$ value of $29.8 \mathrm{~mL} / \mathrm{g}$.

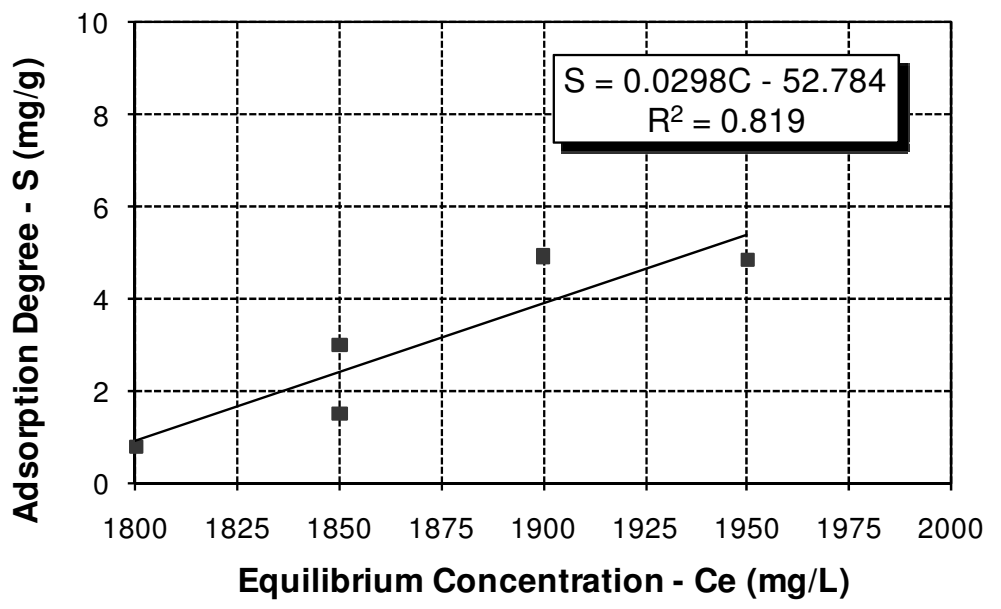

Fig. 18. Linear sorption isotherm obtained for potassium from leachate and a soil sample taken from a MSW disposal site in Brazil (Mondelli, 2008)

\section{Conclusion}

The chapter shortly presented and discussed the steps of a geo-environmental site investigation program for municipal solid waste disposal sites, and also, different and modern in-situ and laboratory test techniques for this purpose. A literature research was conducted on different areas of knowledge, comprising the current problems on the inadequate disposal of waste, environmental liabilities and techniques for the investigation of contaminated sites. Research results on Environmental Geotechnics were also included, aimed at the appropriate monitoring and proper installation of sanitary landfills. Therefore, it can be concluded that it is fundamental to know exactly all the goals, local interests, background factors and resources involved in each case, for an effective and optimized geoenvironmental site investigation. This approach will provide positive results for the local population and for the physical environment. 


\section{Acknowledgments}

The authors gratefully acknowledge the Brazilian research agencies FAPESP (State of São Paulo Research Foundation), CAPES (Brazilian Federal Agency for Support and Evaluation of Graduate Education) and $\mathrm{CNPq}$ (National Council for Scientific and Technological Development) for funding their researches.

\section{References}

ABNT NBR - 13600 (1996). Solo - Determinação do Teor de Matéria Orgânica por Queima a $440^{\circ} \mathrm{C}$. Brazilian Association for Technical Standards, São Paulo-SP, Brazil.

APHA, AWWA, WEF (1995). Standard Methods for the Examination of Water and Wastewater. American Public Health Association, American Water Works Association, Water Environmental Federation. Managing Editor Mary Ann H. Franson. 19th Edition, U. S. A., pp. 3-1 - 3-2.

ASTM D 5778-07. Standard Test Method for Electronic Friction Cone and Piezocone Penetration Testing of Soils. ASTM International, Pennsylvania, U.S.A.

ASTM D 4646- 03 (Reapproved 2008). Standard Test Method for 24-h Batch-Type Measurement of Contaminant Sorption by Soils and Sediments. ASTM Intern., Pennsylvania, U.S.A.

ASTM C 1733-10. Standard Test Method for Distribution Coefficients of Inorganic Species by the Batch Method. ASTM Intern., Pennsylvania, U.S.A.

Anirban, D. E.; Matasovic, N. \& Dunn, R. J. (2004). Site Characterization of Five Hazardous Waste Landfills. Proceedings of the $2^{\text {nd }}$ International Conference on Site Characterization, Porto, Portugal, September 2004, pp. 1075-1080.

Archie, G. E. (1942). The Electrical Resistivity Log as an Aid in Determining Some Reservoir Characteristics. Transactions of American Institute of Mining and Metallurgy Engineering, Vol.146, pp. 54-62.

Azevedo, I. C. D.; Nascentes, C. R.; Matos, A. T. \& Azevedo, R. F. (2006). Determination of Transport Parameters for Heavy Metal in Residual Compacted Soil Using Two Methodologies. Canadian Journal of Civil Engineering, Vol.33, pp. 912-917.

Azevedo, I. C. D. , Nascentes, C. R.; Azevedo, R. F.; Matos, A. T. \& Guimarães, L. M. (2003). Coeficiente de Dispersão Hidrodinâmica e Fator de Retardamento de Metais Pesados em Solo Residual Compactado. Solos e Rochas, Vol.26, pp.229-249.

Barone, F. S.; Yanful, E. K.; Quigley, R. M. \& Rowe, R. K. (1989). Effect of Multiple Contaminant Migration on Diffusion and Adsorption of Some Domestic Waste Contaminants in a Natural Clayey Soil. Canadian Geotechnical Journal, Vol.26, pp. 189-198.

Bolinelli Jr., H. L. (2004). Piezocone de Resistividade: Primeiros Resultados de Investigação Geoambiental em Solos Tropicais. MSc, Department of Civil Engineering, São Paulo State University, Bauru-SP, Brazil.

Boscov, M. E. G.; Cunha, I. I. \& Saito, R. (2001). Radium Migration Through Clay Liners at Waste Disposal Sites. Science of the Total Environment, Vol.266, pp. 259-264.

Campanella, R. G. (2008). Geo-Environmental Site Characterization. Proceedings of the $3^{\text {rd }}$ International Conference on Geotechnical and Geophysical Site Characterization, Taipei Taiwan, Taylor \& Francis Group, pp. 3-16.

CETESB (2005). Relatório de Estabelecimento de Valores Orientadores para Solos e Águas Subterâneas no Estado de São Paulo. São Paulo-SP, Brasil. 
Cherry, J. A.; Gillham, R. W.; Anderson, E. G. \& Johnson, P. E. (1983). Migration of Contaminants in Groundwater at a Landfill: a Case Study 2. Groundwater Monitoring Devices. Journal of Hydrology, Vol.63, pp. 31-49.

Christensen, T. H., Bjerg, P. L. \& Kjeldsen, P. (2000). Natural attenuation: a feasible approach to remediation of ground water pollution at landfills? Ground Water Monitoring $\mathcal{E}$ Remediation, Vol.20, pp. 69-77.

Dahlin, T.; Bernstone, C. \& Loke, M. H. (2002). A 3-D Resistivity Investigation of a Contaminated Site at Lernacken, Sweden. Geophysics, Vol.67, pp. 1692-1700.

Daniel, C.R. (1997). An Investigation of the Factors Affecting Bulk Soil Electrical Resistivity. BASc, University of British Columbia, Department of Civil Engineering.

Davies, M. P. \& Campanella, R. G. (1995). Environmental Site Characterization Using In-Situ Testing Methods, $48^{\text {th }}$ Canadian Geotechnical Conference, Vancouver-BC, Canada.

Elis, V. R. \& Zuquette, L. V. (2002). Caracterização Geofísica de Áreas Utilizadas para Disposição de Resíduos Sólidos Urbanos. Revista Brasileira de Geociências, Vol.32, pp. 119-134.

Frempong, E. M. \& Yanful, E. K. (2008). Interactions Between Three Tropical Soils and Municipal Solid Waste Landfill Leachate. Journal of Geotechnical and Geoenvironmental Engineering, Vol.134, pp.379-396.

Freeze, R. A. \& Cherry, J. A. (1979). Groundwater. Prentice Hall, Inc. Englewood Cliffs, New Jersey, U. S. A.

Geoprobe Direct Image (2004). MP 6500 - Membrane Interface Probe (MIP): User Manual. Document N. 3083, Revision 1.0 10-12-2004, Kejr, Inc., Salina, Kansas, U.S.A.

Grazinolli, P. L.; Costa, A.; Campos, T. M. P. \& Vargas Jr., E. A. (1999). Aplicações do Radar de Penetração no Solo (GPR) e da Eletrorresistividade para a Detecção de Compostos Orgânicos. Proceeding of the $4^{\circ}$ Congresso Brasileiro de Geotecnia Ambiental, São José dos Campos, Brazil, December 1999, pp 127-13.

Innov-X Systems Alpha Series (2007). X-Ray Fluorescence Spectrometers. P/N 100392, Revision B. Woburn, MA, U. S. A.

IPT (2011). Estudo de Viabilidade para Ampliação da Área de Disposição Final de Resíduos Sólidos Urbanos no Município de Anhembi-SP. Institute for Technological Research, Center for Energy and Environmental Technologies. Parecer Técnico 19455-301/11, complementar ao Parecer Técnico 19287-301/11.

Kjeldsen, P.; Bjerg, P. L.; Rügge, K.; Christensen, T. H. \& Pedersen, J. K. (1998). Characterization of an Old Municipal Landfill (Grindsted, Denmark) as a Groundwater Pollution Source: Landfill Hydrology and Leachate Migration. Waste Management \& Research, Vol.16, pp. 14-22.

Lago, A. L.; Silva, E. M. A.; Elis, V. R. \& Giacheti, H. L. (2003). Aplicação de Eletrorresistividade e Polarização Induzida em Área de Disposição de Resíduos Sólidos Urbanos em Bauru-SP. Proceedings of the $8^{\text {th }}$ International Congress of the Brazilian Geophysical Society, Rio de Janeiro, Brazil, November 2003, CD-ROM.

Lambe, T. W. \& Whitman, R. V. (1969). Soil Mechanics. New York: J. Wiley, 553p.

Lan, T. N. (1977). Um Nouvel Esai D'identification des Sols: L'essai au Bleu de Methyléne. Bulletin Liaison Laboratoire dês Ponts et Chaussée, Paris, pp.136-137.

Larsson, R. (1995). Use of a Thin Slot as Filter in Piezocone Tests. Proceedings of International Symposium on Cone Penetration Testing (CPT'95), Linköping, Sweden, pp. 35-40. 
Leite, A. L. \& Paraguassú, A. B. (2002). Diffusion of Inorganic Chemicals in Some Compacted Tropical Soils. Proceedings of the 4th International Congress In Environmental Geotechnics, Rio de Janeiro, Brazil, August 2002, pp 39-45.

Loke, M. H. \& Barker, R. D. (1996). Practical Techniques for 3D Resistivity Survey and Data Inversion. Geophysical Prospecting, Vol.44, pp. 499-523.

Lunne, T.; Robertson, P. K. \& Powell, J. (1997). Cone Penetration Test in Geotechnical Practice. Blackie Academic \& Professional, London.

Mackay, D. M.; Freyberg, D. L.; Roberts, P. V. \& Cherry, J. A. (1986). A Natural Gradient Experiment on Solute Transport in a Sand Aquifer: 1. Approach and Overview of Plume Movement. Water Resources Research, Vol.22, pp. 2017-2029.

MacFarlane, D. S.; Cherry, J. A.; Ghillham, R. W. \& Sudicky, E. A. (1983). Migration of Contaminants in Groundwater at a Landfill: a Case Study, 1. Groundwater Flow and Plume Delineation. Journal of Hydrology, Vol.63, pp. 1-29.

McNeill, J. D. (1980). Electromagnetic Terrain Conductivity Measurement at Low Induction Numbers. Geonics Technical Note, No.6, 15p.

Mondelli, G. (2008). Integração de Diferentes Técnicas de Investigação para Avaliação da Poluição e Contaminação de uma Área de Disposição de Resíduos Sólidos Urbanos. Ph.D. Thesis, Department of Geotechnical Engineering, University of São Paulo, São Carlos-SP, Brazil.

Mondelli, G.; Giacheti, H. L.; Boscov, M. E. G.; Elis, V. R. \& Hamada, J. (2007). Geoenvironmental Site Investigation Using Different Techniques in a Municipal Solid Waste Disposal Site in Brazil. Environmental Geology, Vol.52, pp. 871-887.

Mondelli, G.; Giacheti, H. L. \& Elis, V. R. (2010a). The Use of Resistivity for Detecting MSW Contamination Plumes in a Tropical Soil Site. Proceedings of $6^{\text {th }}$ International Conference on Environmental Geotechnics, New Delhi, India, pp. 1544-1549.

Mondelli, G.; Giacheti, H. L. \& Howie, J. A. (2010b). Interpretation of Resistivity Piezocone Tests in a Contaminated Municipal Solid Waste Disposal Site. Geotechnical Testing Journal, Vol. 33, N. 2, pp. 123-136.

Monteiro Santos, F. A. (2004). 1-D Laterally Constrained Inversion of EM34 Profiling Data. Journal of Applied Geophysics, Vol.56, pp. 123-134.

Nascentes, C. R. (2003). Coeficiente de Dispersão Hidrodinâmica e Fator de Retardamento de Metais Pesados em Solo Residual Compactado. MSc, Department of Civil Engineering, Federal University of Viçosa, Viçosa-MG, Brazil.

Pejon, O. J. (1992). Mapeamento Geotécnico da Folha de Piracicaba-SP (Escala 1:100.000): Estudo de Aspectos Metodológicos, de Caracterização e de Apresentação dos Atributos. Ph.D. Thesis, Department of Geotechnical Engineering, University of São Paulo, São Carlos-SP, Brazil.

Porsani, J. L.; Malagutti Filho, W.; Elis, V. R.; Fisseha, S., Dourado, J. C. \& Moura, H. P. (2004). The Use of GPR and VES in Delineating a Contamination Plume in a Landfill Site: A Case Study in SE Brazil. Journal of Applied Geophysics, Vol.55, pp. 199-209.

Ritter, E. (1998). Efeito da Salinidade na Difusão e Sorção de Alguns Íons Inorgânicos em um Solo Argiloso Saturado. PhD, Department of Civil Engineering, Federal University of Rio de Janeiro, Rio de Janeiro-RJ, Brazil.

Robertson, P. K. (1998). Geo-Environmental Investigation, Characterization and Monitoring Using Penetration Techniques. Simpósio Brasileiro de Geotecnia Ambiental, São PauloSP, Brazil. 
Robertson, P. K.; Campanella, R. G., Gillespie, D. \& Greig, J. (1986). Use of piezometer cone data, Proc. of the In-Situ-86, ASCE Specialty Conference, p. 1263-1280

Robertson, P. K. \& Cabal, K. L. (2008). Guide to Cone Penetration Testing for Geo-Environmental Engineering. Gregg Drilling \& Testing, Inc., 2nd Edition, 84 p.

Robertson, P. K. \& Campanella, R. G. (1988). Guidelines for Geotechnical Design Using CPT and CPTU Data. Report FHWA, 340p.

Rowe, R. K.; Caers, C. J. \& Barone, F. S. (1988). Laboratory Determination of Diffusion and Distribution Coefficients of Contaminants Using Undisturbed Clayey Soil. Canadian Geotechnical Journal, Vol.25, No.1, pp. 108-118.

Shackelford, C. D. (1993). Contaminant Transport. Geotechnical Practice for Waste Disposal, Chapman \& Hall, London, pp. 33-65.

Shackelford, C. D. (1994). Critical Concepts for Column Testing. Journal of Geotechnical Engineering, Vol.120, pp.1804-1828.

Shackelford, C. D. \& Daniel, D. E. (1991). Diffusion in Saturated Soil. I: Background. Journal of Geotechnical Engineering, Vol.117, No.3, pp. 467-484.

Shinn II, J.D. \& Bratton, W.L. (1995). Innovations with CPT for environmental site characterization", Proceedings of CPT'95, Vol. 2, pp. 93-98.

Stuermer, M. M. (2005). Contribuição ao Estudo de um Solo Saprolítico como Revestimento Impermeabilizante de Fundo de Aterros de Resíduos. PhD, Department of Structures and Geotechnical Engineering, University of São Paulo, São Paulo-SP, Brazil.

Telford, W. M.; Geldart, L. P.; Sheriff, R. E. \& Keys, D. A. (1990). Applied Geophysics, Cambridge University Press, $860 \mathrm{p}$.

Thornthwaite, C.W. \& Mather, J.R. (1955). The water balance. Publications in Climatology. New Jersey: Drexel Institute of Technology, 104p.

US EPA (1989). Seminar on Site Characterization for Subsurface Remediations. United States Environmental Protection Agency, Technology Transfer, Report CERI-89-224, 350p.

US EPA (1993). SW-846 pH in Liquid and Soil. Method 9040 (Liquid) and SW-846 Method 9045 (Soil).

Ustra, A. T.; Elis, V. R.; Mondelli, G.; Zuquette, L. V. \& Giacheti, H. L. (2011). Case Study: A 3D Resistivity and Induced Polarization Imaging from Downstream a Waste Disposal Site in Brazil. Environmental Earth Sciences, in press (online).

Weemes, I. (1990). A Resistivity Cone Penetrometer for Ground-Water Studies. MASc, University of British Columbia, Department of Civil Engineering.

Yong, R. N. (2001). Geoenvironmental Engineering: Contaminated Soils, Pollutant Fate $\mathcal{E}$ Mitigation. CRC Press, USA, 307p

Yong, R. N.; Mohamed, A. M. O. \& Warkentin, B. P. (1992). Principles of Contaminant Transport in Soils. Elsevier Science Publishers B.V., 327 p.

Zuquette, L. V.; Palma, J. B. \& Pejon, O. J. (2005). Environmental Assessment of an Uncontrolled Sanitary Landfill. Bulletin of Engineering Geology and the Environment, Vol.64, pp.257-271. 


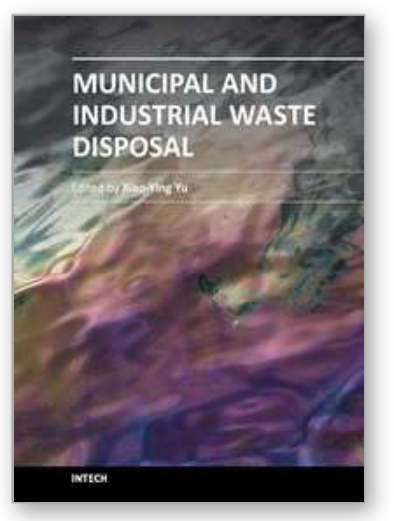

\author{
Municipal and Industrial Waste Disposal \\ Edited by Dr. Xiao-Ying Yu
}

ISBN 978-953-51-0501-5

Hard cover, 242 pages

Publisher InTech

Published online 11, April, 2012

Published in print edition April, 2012

This book reports research findings on several interesting topics in waste disposal including geophysical methods in site studies, municipal solid waste disposal site investigation, integrated study of contamination flow path at a waste disposal site, nuclear waste disposal, case studies of disposal of municipal wastes in different environments and locations, and emissions related to waste disposal.

\title{
How to reference
}

In order to correctly reference this scholarly work, feel free to copy and paste the following:

Giulliana Mondelli, Heraldo Luiz Giacheti and Vagner Roberto Elis (2012). Geo-Environmental Site Investigation for Municipal Solid Waste Disposal Sites, Municipal and Industrial Waste Disposal, Dr. Xiao-Ying Yu (Ed.), ISBN: 978-953-51-0501-5, InTech, Available from: http://www.intechopen.com/books/municipal-andindustrial-waste-disposal/geo-environmental-site-investigation-for-municipal-solid-waste-disposal-sites

\section{INTECH}

open science | open minds

\author{
InTech Europe \\ University Campus STeP Ri \\ Slavka Krautzeka 83/A \\ 51000 Rijeka, Croatia \\ Phone: +385 (51) 770447 \\ Fax: +385 (51) 686166 \\ www.intechopen.com
}

\author{
InTech China \\ Unit 405, Office Block, Hotel Equatorial Shanghai \\ No.65, Yan An Road (West), Shanghai, 200040, China \\ 中国上海市延安西路65号上海国际贵都大饭店办公楼 405 单元 \\ Phone: +86-21-62489820 \\ Fax: +86-21-62489821
}


(C) 2012 The Author(s). Licensee IntechOpen. This is an open access article distributed under the terms of the Creative Commons Attribution 3.0 License, which permits unrestricted use, distribution, and reproduction in any medium, provided the original work is properly cited. 